\begin{tabular}{ccc}
\hline & Contents lists available at Egyptian Knowledge Bank & MICROBIAL BIOSYSTEMS \\
\hline
\end{tabular}

\title{
Antibiotic resistance: Current global issue and future challenges
}

\author{
Rahim AA, Ahmadissa SM, Muhamad LR, Hama Soor TA*
}

Technical College of Health, Sulaimani Polytechnic University, Kurdistan Region of Iraq, Sulaimani City, Iraq.

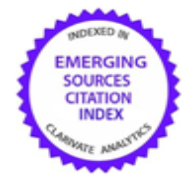

\begin{tabular}{l}
\hline ARTICLE INFO \\
\hline Article history \\
Received 19 October 2020 \\
Received revised 29 October 2020 \\
Accepted 25 December 2020 \\
Available online 10 February 2021 \\
C) Alnweiri 2020 \\
Corresponding Editor: \\
Yadav AN \\
Darwish AGM \\
Abdul-Hadi SY
\end{tabular}

Keywords

Antibiotic resistance

$\beta$-lactamases

Drug resistance epidemiology

\begin{abstract}
Understanding antibiotic resistance and control measure is a challenge because it causes dissemination of multidrug resistance bacteria, and it causes high morbidity and mortality. Bacteria expressing extended spectrum beta lactamases (ESBL) have been recently reported globally at an alarming level and these issues exist in Middle East and Iraq. Bacteria bearing beta lactam resistance genes shows multi-drug resistance and it cause delay in treatment. The huge number of studies has been carried out to indicate the causes of drug resistances and the outcome of this problem in clinical fields. Therefore, this study is about to reviewing different causes and aspects of drug resistances such as: causes of drug resistance, antibiotic resistance mechanisms, antibiotic resistance reversibility, and different types of beta lactamase resistance genes, Resistance Genes (ESBL) in Middle East, and Resistance Genes (ESBL) in Iraq. The review highlighted all research showing the existence of different types of ESBL in humans, animals and environments in different places of Middle East and Iraq. Bacteria bearing $\beta$ lactamases resistance genes have been spread in all parts of Middle East which is public health threating; therefore, it's important to limit Antibiotic use by people. Further research is required in the studied area to understand the reason of antibiotic resistance and an attempt to find new antibiotic is very necessary to save future humans life.
\end{abstract}

Published by Arab Society for Fungal Conservation

\section{Introduction}

Antibiotic resistance is a typical phenomenon that the bacteria uses to survive by using both natural and engineering response strategies in bacterial communities (Canto, Ramo 2009; Cruz et al. 2002). In the last decade, antibiotic resistance emerged rapidly and spread worldwide, which lead to identify as a threat to the public health by numerous public health organization and Center for Disease and Prevention (CDC) (Rice et al. 2020; Frieden 2013). CDC has classified germs as urgent, serious, concerning threat and watch list that includes three uncommon threats (Roca et al. 2015). According to a CDC report in 2019, numerical data reveals more than 2.8 million antibiotic

resistance infection occur in US each year and more than 35 thousand people die consequently (Frieden 2013). Many recommendations and decisions have been proposed, with various reports written, in order to diminish the rate of antibiotic resistance propagation. Unfortunately, distribution of antibiotic resistance have not been extremely reduced, and is still a continuous issue (Roca et al. 2015; Wang et al. 2018), that causes many potential problems in health care system (CDC 2013; Golkar et al. 2014; Lushniak 2014; Rossolini et al. 2014), such as the treatment of pathogenic bacteria becoming harder, developing large numbers of bacterial disease, and increasing the cost of

\footnotetext{
* Corresponding author

E-mail address: taib.ahmed@spu.edu.iq (Taib Ahmed Hama Soor)
} 
treatment (Frieden 2013). Mobile genetic element (insertion sequence, transposon, conjugative plasmid) and spreading of antibiotic resistance genes (ARGs) between bacterial species via horizontal gene transfer (HGT), make large trouble in the battle against antibiotic resistance (Musovic et al. 2006; Johnsen et al. 2012; Partridge et al. 2018). HGT, the non-vertical transportation of genetic material occur through different mechanisms: conjugation, transduction, transformation, and gene transfer agent (Wintersdorff et al. 2016). Some bacterial species naturally resist some types of antibiotic due to mutation in DNA or acquired extra DNA harboring resistance genes such as plasmid (Canto, Ramo 2009; Cruz et al. 2002).

Improper use of antibiotic is a global health problem which is the main cause of antibiotic resistance (Al-tawfiq et al. 2010). Antibiotic resistance happens innately, but wrong use of antibiotics in humans and animals increase the speed of the work (WHO, 2020), leading to an important worldwide risk of growing affect in the human, animal and the public health. This is owing to the rapid disseminate and continuity of multidrug-resistant bacteria or "superbugs" (Wang et al. 2018). In developing countries, it is believed that antibiotic resistance of bacterial pathogens is considered to be high and elevating (Okeke et al. 2005). The worldwide antibiotic resistance is due to increase utilization of antibiotics in foods and water of animals and pets, excess consumption of antibiotics by humans, use of antibiotics without prescription, bad infection control practices in hospitals, increase multinational journeys, bad sanitization/cleanliness, and the releasing of nonmetabolized antibiotics or their remaining part into the surrounding environment throughout dungs and stools (Wang et al. 2018). All of these are reasons leading to the genetic selection pressure for the emergence of a multi-drug resistance bacterial disease in society (Al-tawfiq et al. 2010; Wang et al. 2018). The growing of numeral infections - for example pneumonia, tuberculosis, gonorrhea, and salmonellosis - these are becoming difficult to deal with as the antibiotics used to treat them become less efficient (WHO, 2020).

Antibiotic consuming has intensive impact on human health and even animals positively. However, the intensive use of antibiotics (which was estimated in 2002 to be 100,000-200,000 tonnes per annum worldwide (Wise 2002; Andersson, Hughes 2010) and which is, in total, well over 1 million tonnes since the 1940 s has dramatically increased the frequency of resistance among human pathogens and threatens a loss of therapeutic options and a post-antibiotic era in which the medical advances to date are negated (Guay, 2008; Woodford, Livermore 2009; Review et al. 2017). Resistance becomes a clinical problem that affects the effectiveness of the drug therapy (Andersson and Hughes 2010). The level of exposure of the pathogen population to the drug influences the selection of resistant variants (Bergman et al. 2004, 2009). Resistance reduces the drug action on pathogens and infection treating and increasing the risk of complications and fatal outcomes (Andersson and Hughes 2010). Resistance is often associated with reduced bacterial fitness, and it has been proposed that a reduction in antibiotic use and, therefore, in the selective pressure to acquire resistance would benefit the fitter susceptible bacteria, enabling them to outcompete resistant strains over time (Levin et al. 1997; Andersson and Levin 1999).

This study aimed to review different causes and aspects of drug resistances. Bacteria bearing $\beta$-lactamases resistance genes have been studies well in all parts of Middle East and Iraq which is health concerning. All species of bacteria harboring $\beta$-lactamases resistance genes has been shown; therefore it's important to limit Antibiotic use by people in the area of the study. Further researches are required in the studied area to understand the reason of antibiotic resistance and an attempt to find new antibiotic is very necessary to save future humans life.

\section{Causes of antibiotic resistance}

\section{Societal causes}

The overuse and misuse of antibiotics are main cause for the development of antibiotic resistance (Bonten et al. 2001; Bertrand and Hocquet 2017). Epidemiological studies have indicated a direct association of antibiotic consumption with the emergence and spread of resistant strains of bacteria (Nature 2013; Mobarki et al. 2019). Inappropriate antibiotic prescriptions contribute to upgrade of resistant bacteria. Studies have demonstrated that in 30\% to $50 \%$ of cases, treatment indication, choice of agent, or duration of antibiotic consumption is incorrect (CDC 2013; Luyt et al. 2014; Mobarki et al. 2019). Sub-inhibitory antibiotic concentrations can encourage the progress of antibiotic resistance through facilitating of genetic alterations, such as changes in gene expression modification, mutagenesis, and horizontal gene transfer (HGT) (Viswanathan 2014). Alteration in gene expression, which induced by antibiotics, can increase virulence and pathogenicity, while increased mutation rate and HGT contribute to antibiotic resistance and dissemination. For example, strain diversification in Pseudomonas aeruginosa was detected, resulting from using subinhibitory concentrations of antibiotics (Viswanathan 2014; Mobarki et al. 2019).

Another cause is a wide range of using antibiotics in agriculture (Bartlett et al. 2013; Perović et al. 2018), effecting the animals and become a source of distribution for the antibiotic resistance genes (ARG) (Fitzpatrick and Walsh 2016). Then, spreads of ARG in soil, water polluted by fecal of animals and environment cause to transmit to 
humans through the food supply. These bacteria which carry ARB can cause infections in humans and may lead to adverse health consequences (CDC 2013). Availability of few new antibiotics, antibiotic research team has been reduced in pharmaceutical companies due to funding cuts and the economic crisis (Piddock 2012). But reduction in clinical trials for antibiotic development is no longer thought about due to economical reason, but because antibiotics are used for relatively short periods, and because antibiotics are not profit-making as drugs that are used for the treatment of chronic conditions, such as diabetes mellitus, psychiatric disorders, asthma, or gastroesophageal reflux (Piddock 2012; Bartlett et al. 2013; Gould, Bal 2013; Golkar et al. 2014).

The other factors that have led to this problem include the obtainability, general affordability and ease of use of antibiotics (Piddock 2012; Bartlett et al. 2013; Gould and Bal 2013; Wright 2014) and also, using antibacterial products for cleaning purposes may contribute to antibiotic resistance and limit the development of immunities to environmental antigens in humans (Golkar et al. 2014; Michael et al. 2014). Application in pharmaceutical industry still overlooked until now (Oran 2016).

\section{Biological causes}

Selective pressure is a general concept that refers to many factors, which form an environmental condition and enable organism with novel mutations or newly acquired characteristics, so that they survive and proliferate (Mcgowan 1996; Baquero and Negri 1998). The most often proposed hypothesis about the beginning of antibiotic resistance, is that originated from resistance genes in antibiotic producing organisms, they used these genes to prevent self-inhibition (DAvies 1992). Then, these genes may have transmitted to the bacterial organism in the vicinity. These bacteria may have modified DNA sequence of the acquired genes, which may have used to eliminate of antibiotics. Spread of naturally produced antibiotic in environment and presence in soil and water in a highly diluted concentration. All these hypotheses point to advancement of antibiotic resistance due to a selective force of natural antibiotics, but it is unbelievable that many of the very efficient mechanisms of resistance derived from natural antibiotics selective pressures. Surely, most data support that the highly resistance bacteria may have originated from strong selective force due to massive use of manufacturing antibiotics in medicine and agriculture (Mcgowan 1996).

Bacterial species can share genetic material with related and unrelated species (Ochman et al. 2000; Koonin et al. 2001), by horizontal gene transfer. HGT is the acquisition of foreign genes by organisms (Senka et al. 2008), which is associated with acquired resistome (Hu
2017). Antibiotic resistance genes may be transferred by one of the mechanisms of HGT, including conjugation, transformation, and transduction (Sitaraman 2018). Conjugation is the process of transformation of the DNA molecule (plasmid or conjugative transposon) via the conjugation apparatus (physical attachment between donor and recipient cell) (Zechne 2000; Senka et al. 2008). Conjugation is the major identified mechanism responsible for emergence of multi-drug resistance in hospital environments (Guglielmetti et al. 2009; Lerminiaux and Cameron 2019). Also, responsible for the spreading of different antibiotic resistance genes in the Enterobacteriaceae family (Bello-López et al. 2019). Transformation is another HGT mechanism, which is absorption, incorporation, and expression of exogenous DNA from closely related bacteria (Lorenz and Wackernagel 1994). Transduction is DNA acquisition, which is arbitrated by independently replicating bacteriophages, bacterial viruses that mistakenly collect segments of host DNA in their capsid, and then inject it into a new host cell (Arber 2014; Bello-López et al. 2019). Both biological and societal causes coordinate together and lead to emerge antibiotic resistance.

\section{Antibiotic Resistance Mechanisms}

Bacteria have great genetic flexibility which permits them to make a response against wide range of ecological menaces, such as antibiotic molecules that may pose a threat to their presence. Bacteria defend themselves against antibiotics through many mechanisms, in general realization the mechanisms in which bacteria use to fight antibiotics will be helpful for resolving the difficulties. Inappropriate use of antibiotics involves in the evaluation of resistant bacteria. Uncompleted course of antibiotics run the possibility of not completely eliminating the colony, thus contribute to growing of resistant bacteria. There are several type of drug resistance mechanisms including efflux pumps, drug deactivation or alteration, modification of drug binding sites or targets, alteration in cell permeability leading to decrease accumulation of drugs within cells, formation of biofilms and others (Wilson 2014; Ali et al. 2018).

In bacteria one of the main factors contributing to drug resistance is efflux pumps; it transmits a wide range of antibiotics to the outside the organism (Giedraitiene et al. 2011). Thus, it can be difficult to treat infections caused by these pathogens (Mckeegan et al. 2003). Efflux pumps are transport proteins that contribute in removing toxic substances from inside to the outside of the cell. Some efflux pumps are intended for one drug while others are able to transport various substrates, and the genes of the efflux pumps can be self or acquired (Yalew 2020). 
Bacteria use different mechanisms to develop antibiotic resistance including antibiotic inactivation, enzyme hydrolysis of antibiotics, group transfer and process of redox. A typical example of antibiotic inactivation is $\beta$ - lactamases production that hydrolyses the $\beta$-lactam ring of penicillin. The first mechanism is secretion of enzymes that lead to antibiotic inactivation before reaching its target inside the bacteria. The second mechanism is drug structural alteration by functional group transferring such an acyl, phosphoryl or ribosyl (Yalew 2020). The antibiotic incapable to bind the target due to the structural change (Varela and Kumar 2014).

Target modification is another antibiotic resistance mechanism. Alteration of antibiotic binding site inhibits antibiotic to bind to the target site properly. Bacteria modify the target of antimicrobial agent (Yalew 2020). Typical drug target modification example is staphylococcal mechanism, that modifies the penicillin binding protein (PBP), which is a target for $\beta$-lactam antibiotics (Davies and Davies 2010).

Antimicrobials mostly need to enter the cell of microbe in order to take action on its target site. So, reducing entry of antimicrobial agents by the microbes is one of the mechanisms of antimicrobial resistance. Antibiotics pass through prion channels to enter the bacterial cell (Yalew 2020). Some bacteria inhibit antimicrobial accessing into them thus they can protect themselves (Poole 2002). Mutation is sudden alteration in the genetic material generally causes to a change in the end-product of the mutant gene or in a phenotype (Ali, Rafiq, Ratcliffe, 2018; Yalew 2020). Substitution (replacement of a nitrogenic base by another type), deletion (the removal of bases causes to alter in the codons), addition (insertion), inversion and duplication deficiency are the five mechanisms of genetic mutation (Coculescu 2005, 2009). Spontaneous mutation in bacterial chromosomes occur rarely (one mutation in 106108 individuals in a population), due to deficiencies in DNA replication processes and incorrect DNA repair mechanism (Rice and Sahm 2003; Giedraitienè et al. 2011). Despite, certain resistance genes have derived through accidental mutations (Todar 2008; Coculescu 2009).

Antibiotic resistance can be attained by adaptive mutations in bacterial genome. Under the stress of antibiotics, the rate of mutation increased in pathogenic bacteria and they become hypermutant (Mihăescu and Chifiriuc 2007). For example, some bacteria during the stress of antibiotics start to exchange their genes that are necessary for the production of proteinic substances. These proteinic substances play a role inside the cell, to augment the rate of mutation that is 10,000 times faster than the rate of mutation in normal condition of binary cell division (Kaiser 2007; Coculescu 2009). Also, low antibiotic concentrations, short time of exposure, slow rate of killing by antibiotic, starvation, pathogenic stress, bacteria with hypermutable phenotype, unstable sequences surrounding the nucleotides responsible for the resistance phenotype, and long distance between resistance gene and origin of replication, are all factors that rise the rate of antibiotic resistance mutation (Baquero 2000).

Mutations in a single gene (independent mutation) can reveal resistance phenotype. For example, resistance to some quinolones result from alteration in the gene codes either GyrA or GyrB subunit of topoisomerase II (Nakamura et al. 1989). Whereas, in some cases, mutations in several different genes (cooperative mutation) are required to develop resistance. For instance, mutations in gyrA and grlA genes and also in efflux pump regulatory sequence, together result in high level fluroquinolone resistance (Munoz 1999; Baquero 2000).

Mutation cooperates and effects the other mechanisms, such as mutations in rpoB in S. aureus and M. tuberculosis, lead to alter the target of Rifampin and lessen affinity to $\beta$ lactam antibiotics results of the mutation in penicillin binding proteins (PBPs) (Rice and Sahm 2003; Wright 2005; Chen et al. 2011; Giedraitienė 2011). Microbial biofilm is the complicated network of assembled microbial communities, which embedded in an extracellular polymeric substance such as proteins, exopolysaccharides (EPS), extracellular DNA (e-DNA), and amyloidogenic proteins (Whitchurch et al. 2002; Donlan 2001; Jost 2001; Sharma et al. 2019). Together form a matrix in multistep process, beginning from adsorption of molecules to surfaces, then, bacterial adhesion and release of extracellular substances, finally, microbial colony formation and biofilm growth and maturation (Flemming et al. 2016; Sharma et al. 2019). Microbial biofilms have great role in antibiotic resistance, because biofilm-associated microorganisms present reduced rate of the susceptibility to antibiotics (Williams et al. 1997; Ceri et al. 1999; Todar 2008).

Biofilm community increases resistance rate through many strategies, including slow or insufficient penetration of the antibiotics into the biofilm due to presence EPSs, which is able to hold up the diffusion rate of antibiotics in the biofilm (Hoyle et al. 1992; Donlan 2001). The alterations of chemical environment ( $\mathrm{pH}$, osmolarity...) that enclose the cells within a biofilm, may provide further protection of microorganism (Gordon et al. 1988; Hausner and Wuertz 1999; Maya-hoyos et al. 2015; Sharma et al. 2019). And increased rates of horizontal plasmid transportation by conjugation have been observed in a biofilm, that higher than its rate in a liquid culture of the same organism. Such as, an investigation indicated that transference of plasmid between gram negative bacteria by conjugation raised in biofilms (Christensen et al. 1998; Ehlers 1999; Hausner and Wuertz 1999; Roberts et al. 1999; Donlan 2001). All these strategies in biofilms result 
in the increased rates of antibiotic resistance correspondingly.

\section{Antibiotic resistance reversibility}

A reduction in antibiotic prescribing is one strategy to decreasing the development and spreading of antibiotic resistance, and it promotes reversing of resistance, through decreasing the selective pressure (Runehagen et al. 2010; Holmes et al. 2015). Reversibility of resistance is theoretically attractive, while its investigation difficult in practice (Sundqvist 2014). Despite whole eradication of antimicrobial resistance, only by reducing selective pressure is not straightforward (Johnsen et al. 2009; Holmes et al. 2015).

Microbes can acquire resistance easily, and persistence of antimicrobial resistance microbes can occur on human and animal skin and as fecal flora, for many years without any exposure to antimicrobial substance or under selection pressure (Sjölund et al. 2003). There is an obvious relation between heavy antibiotic consumption within a population and the recovery of resistant bacteria, but the process of reversing antibiotic resistance by reductions in antibiotic use is less clear (Enne et al. 2001).

Many studies were done in order to find more information about resistance reversibility. Such as, a prospective study was performed in Kronoberg County, Sweden in 2004. An antibiotic intervention was performed for 24 months, 464 physicians were requested to substitute trimethoprim-containing antibiotics $(85 \%$ reductions in use during the intervention) with other antibiotics (pivmecillinam, nitrofurantoin and ciprofloxacin), for the treatment of urinary tract infection, that caused by E. coli. The result was marginal effects on the resistance frequency, but statistically significant effect on the increase in trimethoprim resistance was registered, due to a low fitness cost and co-selection due to high levels of associated resistance.

The author summarized that the antibiotic cycling strategy will not be useful, unless non-using period is much longer than 24 months, the fitness cost of resistance is distinctly higher than that seen for trimethoprim resistance in E. coli, and the replacement drugs must be devoid of associated resistance (Runehagen et al. 2010). In contrast, both studies, erythromycin-resistant S. pyogenes in Finland and penicillin-resistant S. pneumoniae in Iceland, showed greatly reduced resistance rates after decreasing the use of these antibiotics (Kristinsson 1997; Seppala et al. 1997; Runehagen et al. 2010). Another study in Korea revealed that the decrease in erythromycin resistance was caused by decreasing of a certain resistant emm-type of S. pyogenes rather than decreasing of erythromycin usage (Koh, Kim 2010).
Reversing resistance only by reducing antibiotics use alone is inadequate, because many several factors help to persist resistance without the presence of selective pressure (Lopatkin et al. 2017). Such as co-selection, which is a connection between resistance and other characteristics (Baker-austin et al. 2006). On the other side, several factors such as genetic factors and evolutionary processes have been identified, which may help reverse of resistance in the absence of selective pressure (Comas et al. 2012).

Depending on the genetic biological process, three types of resistance reversion were recognized (Bonhoeffer et al. 2017):

First, isogenetic reversion is recovery of the ancestral sensitive genotype, which was predominant in the population before become resistant. Isogenetic reversion mechanisms are regrowth, reinvasion and mutation for chromosomal resistance, and losing of resistance genes require for horizontally transferred resistance (Foucault et al. 2010; Baym et al. 2016). Coexistence of sensitive and resistance strains together is possible after reduction of antibiotic uses, especially using antibiotics that stop the growth and duplication of bacteria, instead of killing this reduction help revival of susceptible strains by regrowth and reinvasion (Pader et al. 2016). Possibility of backward mutation depend on several characteristic in the pathogens such as rate of mutability, and pathogen migration (Levin and Walker 2000). Resistance reversion via backward mutation is rare, but its likelihood is higher in the resistance that result from single mutation than multiple mutation such as fluoroquinolones resistance in pathogenic bacteria (Lindgren et al. 2005). Probability of losing resistance gene is higher than backward mutation on the chromosome. Especially resistance genes that are located on plasmid, because losing of plasmid by segregation can occur at high rate, in the absence of positive selection frequency of plasmid reduces consequently (Ponciano et al. 2007; Inca et al. 2011).

Second, paragenetic reversion is reducing of resistance without bringing back of the ancestral genotype through obtaining of additional alleles (Foucault et al. 2010; Baym, et al. 2016). Mutation is the mechanism of paragenetic for both chromosome and horizontally transferred resistance and its possibility is higher than in isogenetic (Bonhoeffer et al. 2017). Mutations in ileS gene in Salmonella enterica Typhimurium and $\mathrm{S}$. aureus can reduce the mupirocin resistance, and completely recovering susceptibility in some cases is an example of paragenetic reversion (Hurdle et al. 2004; Paulander et al. 2007). Potentially the re-evolve of resistance in paragenetic reversion is significant, because the obtained genotype differs from the susceptible ancestor (Vilhelmsson and Tomasz 2000). Resistance deactivation by catting out of resistance genes has been identified on plasmid of E. coli. Removing or deactivation of resistance genes depend on the essentiality of those genes. If 
resistance outcomes of mutations in vital enzymes, such as the ribosome and RNA polymerase, it's lethal to bacteria to delete or deactivate those genes (Gelder et al. 2004; Enne et al. 2006). Alteration in level of gene expression is another mechanism of paragentic reversion (Bonhoeffer et al. 2017). This type of reversion has been detected in vancomycin-variable strains of E. faecium as an insertion sequence in the upstream of the vanHAX operon results in silencing of the VanA resistance phenotype (Sivertsen et al. 2016). And, silencing mutations have been distinguished in plasmid-carrying E. coli, which bring back susceptibility but they able to re-gaining resistance (Enne et al. 2006).

Third, allogenetic reversion is substitution of resistant genotypes by less resistant or sensitive genotypes of the same species or strain, which are not originated from the ancestral genotype (Foucault et al. 2010; Baym et al. 2016). The interactions between different lineages of the same species or strains are important because related strains and species are able to have different characteristic in resistance phenotypes, such as penicillin susceptibility in Streptococcus pyogenes is deferent between species, and proportionately high antibiotic resistance of $E$. coli that differ with clonal complex 87 (Horn et al. 1996; Skurnik et al. 2015). Allogenetic reversion occurs by migration and competition between species, and also transmission and local adaptation effect within-host reversion (Bonhoeffer et al. 2017).

\section{Beta lactamase resistance genes}

There is no agreement on the exact definition of Extendedspectrum beta-lactamases (ESBLs). In general, ESBLs are known as a group of enzymes which can break down antibiotics, be affiliated to the penicillin and cephalosporin groups and make them ineffectual. ESBL has been illustrated as a transportable $b$ lactamase which can be suppressed by tazobactam, clavulanic acid, or sulbactam, and which's coded by genes that can be substituted among bacteria. The presently most common genotype for ESBL is CTX-M (Actions et al. 2004; Paterson and Bonomo 2005a).

Beta-lactamase is generally categorized according to two common schemes: the molecular classification of Ambler and the functional classification of Bush-JacobiMedeiros (Ambler 1980; Bush et al. 1995). The Ambler blactamas- scheme is classified into four classes according to the protein homogeneity of enzymes. Beta-lactamases category A, C and D are b-lactamase enzymes and category B enzymes are metallo-b-lactamases. The Bush-JacobyMedeiros scheme depends on the functional properties of enzymes, that is, the substrate and inhibitory features (Shaikh et al. 2014).

\section{1-SHV type}

The SHV family of b-lactamases seems to be obtained from Klebsiella spp. The predecessor of the SHV class of enzymes, SHV-1, is widely arrive in pneumonia K. In many $K$. pneumonia strains, the encoded gene SHV-1, or its pronounced precursors, LEN-1, is also found inside the bacterial chromosome; The gene for SHV-1 b-lactamase may have evolved as a chromosome gene in Klebsiella and was subsequently attached to a plasmid that diffuse to other species of Enterobacteria (Shaikh et al. 2014). SHV-1 gives resistance to wide ranges of penicillins, such as piperacillin, ampicillin and tigecycline, but not to alternative cephalosporins that replace oxygen (Livermore 1995).

\section{2-TEM type}

TEM-1, for the first time reported in 1965 from E. coli isolation, has features of substrate and inhibition which is alike to those in SHV-1 (Datta and Kontomichalou 1965). TEM-1 is able for hydrolysis of penicillins and the first creation of cephalosporins but is not capable to work over cefalosporin oxymenoids. The first TEM variable with more activity against cephalosporins extended spectrum was TEM-3 (Sirot et al. 1987; Sougakoff et al. 1988). The fist by product of TEM-1 is TEM-2, a shift in the isoelectric point of $\mathrm{pI}$ from 5.4-5.6, cause one amino acid substitution from the original b-lactamase, but it did not alter a substrate feature (Barth et al. 1985). First TEM type B-lactamase to display ESBL phenotype was TEM-3, which is first reported in 1989 (Sougakoff et al. 1988). Later, TEM-3 may not be the first TEM-type ESBL. Klebsiella oxytoca contains a plasmid having the encoded gene for resistance of ceftazidime (Bois et al. 1995). TEM-12 was called responsible b-lactamase. The strain obtained from a neonatal unit that was infected with an outbreak of $\mathrm{K}$. oxytoca producing TEM-1 (Bois et al. 1995).

\section{3-CTX type}

A family of $\beta$-lactamase has risen that inactivate cefotaxime action. It has been found in samples of E. coli, Salmonella enterrica serovar and some Enterobacteriaceae species. (Gazouli et al. 1998). CTX not related to TEM or SHV $\beta$ lactomases very closely (Tzouvelekis et al. 2000). CTX has two unique features, first cefotaxime rapid hydrolysis and another one better inhibited by $\beta$-lactamase inhibitor tazobactam than clavunate (Bradford et al. 1998). CTX M $\beta$-lactamase are from functional group 2 and considered that originate ESBL chromosomal gene of Kluyvera spp (Bush and Jacoby 2012). They can be divided to five groups according to sequences of the amino acids, groups are (CTX M group 1,2,8,9 and 25) (Bonnet 2004). CTX M enzyme differently originated from that of TEM and SHV 
ESBL. TEM ESBL and SHV ESBL produced by amino acid substitution of parent ESBL while CTX M ESBL gained by horizontal gene transfer through transposon or conjugative plasmid using genetic materials. CTX M enzyme gene sequences are highly similar to Kluyvera species $\beta$-lactamase sequences. Enterobacteriaceae CTX M gene surrounding also similar to Kluyvera species chromosome gene surroundings (Olson et al. 2005). CTX M $\beta$-lactamase hydrolyse cephaloridine better than benzyl penicillin and advantageously hydrolyse cefotaxime over ceftazidime (Tzouvelekis et al. 2000). However, this enzyme recorded some hydrolysis of ceftazidime, but it is not enough to provide resistance to the organisms they reside. It has been thought that serine at 237 position that occurs in all CTX M enzymes, has important role in activity of spectrum of CTX M $\square$-lactam (Tzouvelekis et al. 2000). It has been thought $\operatorname{Arg} 276$ is on a position that equivalent to Arg 244 of TEM or SHV ESBLs, although it has been shown that is not essential (Gazouli et al. 1998). Toho 1enzyme crystallographic data showed that interacting flexibility increasing for $\mathrm{b} 3$ strand and $\mathrm{X}$ loop of this enzyme than to other class A $\beta$-lactamase. Hydrogen bond absence near $X$ loop counted for extended spectrum phenotype (Ibuka et al. 1999).

\section{4-OXA type}

The OXA - beta lactamases enzyme was classified as class $\mathrm{D}$ beta lactamases, they act against oxacillin and methicillin in a significant degree, by their enzymatic inactivation, through opening the $\beta$-lactam ring of antibiotics irreversibly (Fisher et al. 2005; Walther-rasmussen and Høiby 2006; Pratt and Mcleish 2010; Antunes and Fisher 2014; Evans and Amyes 2014). The name 'OXA' derived from their abilities to hydrolyze oxacillin (Bush et al. 1995; Shaikh et al. 2014). The OXA-type ESBLs had been identified originally from Pseudomonas aeruginosa isolates (Weldhagen et al. 2003), then, they have been observed in the many gram-negative bacteria, for example, the most common OXA type is OXA-1 which found in $1 \%$ to $10 \%$ of E. coli isolates (Livermore 1995; Paterson and Bonomo 2005b). Their gene are located on both the chromosomes and the plasmids of various bacterial species such as Acinetobacter, Shewanella, Pseudomonas, and Burkholderia (Sanschagrin et al. 1995; Poirel et al. 2010; Antunes and Fisher 2014). This class contains large numbers of heterogeneous enzymes, more than 400 variants recognized (Evans and Amyes 2014). For the classification of this diversiform class, using a value of $\geq 80 \%$ amino acid identity to separate into groups, and within each group $95 \%$ amino acid identity to divide into subgroups (Antunes and Fisher 2014).

\section{5-PER type}

PER is an enzyme among class A beta lactamases. It is not related to other ESBLs strongly, but its catalytic machinery and three-dimensional structure have similarity with the class A superfamily. PER-1 beta-lactamase hydrolyzes penicillins and cephalosporins (cefotaxime, ceftazidime) and aztreonam effectively (Ronco et al. 1993; Nordmannl et al. 1994; Naas et al. 2008). The blaPER-1 gene is predominant in Acinetobacter spp. and P. aeruginosa, also can be found in Salmonella enterica serovar Typhimurium and Providencia rettgeri (Aktas and Poirel 2005; Kolayli et al. 2005). PER-2 shares $86 \%$ amino acid homology with PER-1. BlaPER-2 gene was detected in S. enterica serovar Typhimurium in Argentina in 1996 (Giakkoupi et al. 2000; Naas et al. 2008). It has been found in E. coli, $K$. pneumoniae, Proteus mirabilis, and Vibrio cholerae subsequently (Petroni et al. 2002). The PER-types take part in around 25-27\% homology with TEM- and SHV-type ESBLs (Bauernfeind et al. 1996; Shaikh et al. 2014).

\section{6-GES type}

GES type, also named IBC, is commonly detected in gramnegative bacilli, such as $P$. aeruginosa, E. coli and $K$. pneumoniae. blaGES-1 gene located on plasmid (Giakkoupi et al. 2000; Poirel et al. 2000). At first, GES-1 was observed in a Klebsiella pneumoniae isolate from a newborn patient in France (Poirel et al. 2000). GES-1 is able to hydrolyze penicillins and expanded-spectrum cephalosporins, but it has no hydrolytic activity against Cephamycins and Carbapenems (Shaikh et al. 2014). Also, GES-1 cannot hydrolyze Aztreonam, while most ESBLs do (Naas et al. 2008). GES-2 also hydrolyses carbapenems, but is not so much susceptible to beta lactamase inhibitor because of a 2-bp substitution, resulting in a single Gly170Asn alteration within the catalytic site (Poirel et al. 2001). The first described example of an ESBL that extended its spectrum of activity against carbapenems was GES-2 and then four other forms (GES-4, GES5, GES-6 and GES-8) have been described, all with carbapenemase activity (Yigit et al. 2001).

\section{Other ESBL types}

SOF-1 was found in Enterobacter cloacae isolate from Japan in 1988. It hydrolyses cefotaxime effectively and ceftazidime poorly (Bonnet et al. 2000).

BES-1 was isolated from a Serratia marcescens strain in Brazil in 1996. It resists to aztreonam at a high level. The blaBES-1 gene is plasmid-encoded and it shares $48 \%$ amino-acid similarity with the CTX-M group $1 \mathrm{~b}$-lactamase (Poirel et al. 2005).

BEL-1 was detected in a $P$. aeruginosa strain isolated in Belgium in 2004. It has the ability to hydrolyze most 
expanded-spectrum cephalosporins and aztreonam (Silva et al. 2000; Bogaerts et al. 2007).

TLA-1 was observed in an E. coli isolate from a patient in Mexico in 1993. It is able to hydrolyze expandedspectrum cephalosporins but cannot hydrolyze imipenem and cefoxitin (Silva et al. 2000; Alcantar-curiel et al. 2004).

TLA-2 was isolated from an unknown bacterial strain in Germany in 2002. TLA-2 has good catalytic activity against most cephalosporins but doesn't against penicillins (Girlich et al. 2005; Naas et al. 2008).

SOF-1, BES-2, BEL-1, TLA-1 and TLA-2 are rare ESBLs that have been described, and also many others infrequent type of ESBLs identified such as CME-1 and VE-B-1 (Naas et al. 2008; Shaikh et al. 2014).

\section{Resistance Genes (ESBL) in Middle East}

Antibiotics lead to saving millions of lives, but drug resistance have been observed due to its overuse in clinical fields since its discovered in early 1940s (van Hoek et al. 2011; Frieri et al. 2017). Drug resistance phenomenon impedes the treatment of infectious diseases and claiming a large number of morbidity and mortality (Kon and Kateryna 2016). The emerging of resistance bacteria is increasing dramatically in recent decades and poor sanitation measure control accelerates the dissemination of these bacteria in environments and among patients (Frieri et al. 2017).

Enterobacteriacaea (Gram negative Bacilli) that are found in gastrointestinal tract of animals and humans are common causes of infectious diseases (Tian et al. 2012; Verraes et al. 2013). Gram negative Bacilli are distinct in developing resistance against extended spectrum beta lactam antibiotics because of their ability to produce extended spectrum beta lactamases (ESBL) (Schill et al. 2017).

Poor sanitation, control measure and misuse of antibiotic in both humans and animals in Middles East cause dissemination of drug resistance genes in bacteria in large scales. Furthermore, due to economical and war crises in the area, a large population movement has been observed between countries that causes difficulties in infectious disease and sanitation controls (Dandachi et al. 2019). This review study is to discuss and investigate the existence of different types of resistance genes in Middle East and in Iraq. The epidemiology of beta lactamase resistance genes in different countries of Middle East is well studied in recent years and is illustrated in tables 1-5.

\section{Resistance genes in Iraq}

Iraq is one of the countries of Middle East which is counted as a developing country. Using antibiotics in clinical fields and animal industry is enormous. Selling of antibiotics is not restricted in pharmacy shops and people are free to buy them on shelves. Like middles east, dissemination of drug resistance genes in bacteria is in high and alarming levels in Iraq because of poor sanitation, control measure and wrong use of antibiotics in both humans and animals. In addition, Iraq also faced economical and war crises in the last two decades that caused a large population movement between Iraq cities and neighbor countries. These problems in the country became additional reasons of losing ability to cease the spread of infectious diseases and sanitation controls (Dandachi et al. 2019). The common beta-lactamase resistance genes in different bacteria that exist in Iraq have been shown in this section.

Different types of ESBL gene were reported in Iraq in different clinical fields. In one study which was carried out on patients who have repeated urinary tract infection caused by E. coli, TEM, SHV, and CTX-M1 was recovered in a high level in comparison to non-ESBL genes (Al-mayahie et al. 2016). ESBL producing bacteria, Klebsiella spp. and E. coli harboring six different ESBL genes CTX-15 and SHV, TEM1, OXA1, AMPC were discovered from samples collected in patients and hospital environment. SHV gene was identified only in K. pneumoniae (Huang et al. 2012). The rate of TEM, SHV, CTX-M was found at high rates in $E$. coli, and $K$. pneumonia caused urinary tract infections in Thalassemia Patients. The rate of ESBL in E. coli was blaTEM (81\%), blaSHV (16.2\%), and blaCTX-M (32.4\%). In $K$. pneumonia, the rates were as follow: blaTEM (64.7\%), blaSHV (35.2\%), and blaCTX-M (41.1\%) (Ahmad, Khalil 2019).

The ESBL was reported in bacteria that isolated from clinical infections, Morganella morganii including OXA, SHV, TEM, and CTX-M (Al-muhanna et al. 2016). OXA23/OXA-24 carbapenemase were discovered in $A$. baumannii in a different study in the same bacteria (Kusradze et al. 2011; Ganjo et al. 2016). Another study recorded OXA-23 and OXA-24 producing A. baumannii isolated from hospital environments and respiratory tract of patients (Obeidat et al. 2014). OXA-10 also found infectious strain of P. aeruginosa (Burgh et al. 2018). Acinetobacter baumannii isolated from clinical samples (Wounds, Sputum, UTI, Burns, and blood) was tested to detect ESBL, TEM gene. Out of 39 bacteria, 25 (64.1\%) isolates were positive to TEM genes (Taif et al. 2020).

In another study in north part of Iraq, TEM resistance gene was observed in Proteus bacteria by the rate of $10.3 \%$. All of the isolates harboring TEM were discovered in Proteus mirabilis that recovered from meat of different animals and poultry species (Sabiha et al., 2019). Another study was conducted in the same area to find the rate of TEM and CTX in E. coli isolated from feces of humans and animal species. It was concluded that the rate of CTX-M was significantly high in $E$. coli isolated from human, while TEM was significantly high in $E$. coli isolated from farm chickens. Furthermore, it was detected that the rate of ESBL was obviously higher in those hosts using large 
amount of antibiotic (human and farm chickens) in comparison to wild animals (non-antibiotic users) (Alaa et al. 2020). In another study in Kirkuk, the high rate of CTXM-G2 gene was discovered in S. aureus, E. faecalis and Klebsiella spp. isolated from blood of patients in hemodialysis unit of the hospital (Shaker et al. 2020).

In a new study in southern part of Iraq, CTX-M1 resistance gene was detected in E. coli and $K$. pneumonia. Bacteria were isolated from urinary tract infection with high rates of CTX-M1, 29.8\% (E.coli) and $23.8 \%$ ( $K$. pneumonia) (Nasser et al. 2018). In the same area, CTX.M was recovered at the rate of $30 \%$ in environmental $\mathrm{P}$. aeruginosa isolated from tap and sewage water in Baghdad (Khdair et al. 2017).

\section{Conclusion}

Currently, antibiotic resistance is a worldwide issue, and it causes high morbidity and mortality. Existence of EXBL (OXA, TEM, CTX, CMY) in gram negative bacteria are mostly responsible of the emergence of multidrug resistant bacteria. Dissemination of multidrug resistant bacteria is common in the world which causes difficulty in treatment and result in a high mortality. Many studies recorded the existence of multidrug resistant gram-negative bacteria in Middle East and Iraq and most of them bearing ESBL. EXBL in Iraq is common and all types of ESBL are reported in high rates. Drug resistant genes are discovered in humans, animals, and even environments. The spread of multidrug resistant bacteria expressing EXBLs is related to many reasons such as: selling of antibiotics without physician prescriptions, using of antibiotics in poultry industry in large scales, lack of proper health education to people regarding using antibiotics, lack of proper sanitation, economic crisis of the country in different times because of different issues, movement of people between cities for different reasons, fleeing of people from war places to safer cities in different times.

\section{Declaration of competing interest} interests.

The authors declare that they have no competing

\section{Acknowledgements}

We would like to thank Technical college of Health and the presidency of Sulaimani polytechnic University to their collaborations.

\section{Funding}

No funding was used to conduct this research.

\section{References}

Abdalhamid B, Albunayan S, Shaikh A, et al (2017) Prevalence study of plasmid-mediated AmpC b lactamases in Enterobacteriaceae lacking inducible amp C from Saudi hospitals. J. Med. Microbiol 66:1286-1290. doi: 10.1099/jmm.0.000504. doi: 10.1309/LMDQQW246NYAHHAD

Abd RM, Ibrahim RA, et al (2020a) Prevalence of Virulence Genes and Their Association with Antimicrobial Resistance Among Pathogenic E . coli isolated from Egyptian patients with different clinical infections. Infection and Drug Resistance. 13:1221.

Abdalhamid B, Elhadi N, Alabdulqader N, et al (2016) Rates of gastrointestinal tract colonization of carbapenem-resistant Enterobacteriaceae and Pseudomonas aeruginosa in hospitals in Saudi Arabia. New Microbes New Infect 10:77-83.

Abdallah HM, Wintermans BB, Reuland EA, et al (2015) Extended-spectrum $\quad \beta \quad$-Lactamase- and Enterobacteriaceae isolated from Egyptian patients with suspected blood stream infection. Plose One 10(5):e0128120. doi: 10.1371/journal.pone.0128120

Abdeen, E., Elmonir, W., Suelam, I. I. A., and Mousa WS (2018) Antibiogram and genetic diversity of Salmonella enterica with zoonotic potential isolated from morbid native chickens and pigeons in Egypt. J Appl Microbiol 124, 1265-1273. doi: 10.1111/ijlh. 12426

Abdelaziz MO, Bonura C, Aleo A, et al (2013) Cephalosporin resistant Escherichia coli from cancer patients in Cairo , Egypt. Microbioloogy and Immunology 57(5): 391-395. doi: 10.1111/13480421.12046

Abdulhussein TM, Abed AS, Al-Mousawi HM, Abdallah JM, Sattar RJ (2020) Molecular genotyping survey for bla TEM Virulence Gene of Acinetobacter baumani isolates, Iraq. Plant Archives 20:413-415.

Abo-amer AE, Shobrak MY, Altalhi AD (2018) Isolation and antimicrobial resistance of Escherichia coli isolated from farm chickens in Taif, Saudi Arabia. Integr Med Res 15:65-68. doi: 10.1016/j.jgar.2018.05.020

Actions A, Washington CW, Asm DC, et al (2004) Antibiotics: actions, origins, resistance. Protein Science: A Publication of the Protein Society 13:3059-3060.

Ağin H, Ayhan FY, Gülay Z, Gülfidan G, Yaşar N, Eraç B, Devrim I. (2011) The evaluation of clusters of hospital infections due to multidrug-resistant Salmonella enterica serovar typhimurium in the neonatal unit: a two-year experience. Turk J Pediatr, 53(5):517-21. 
Table 1 Epidemiology of beta lactamases resistance gene, CTX in Middle East.

\begin{tabular}{|c|c|c|c|c|}
\hline \multicolumn{5}{|c|}{ CTX } \\
\hline \multicolumn{5}{|c|}{ Acinetobacter baumannii } \\
\hline Egypt & CTX-M-15 & Human & $\begin{array}{l}\text { Wound, burns infection, patients attended in } \\
\text { ICU (from buccal cavity, skin swab and eye } \\
\text { swab) }\end{array}$ & (El-baky et al. 2020) \\
\hline Iran & $\begin{array}{l}\text { CTX-M-2, } \\
\text { CTX-M-9 }\end{array}$ & Human & $\begin{array}{l}\text { Endotracheal tube, urine, blood, wound, body } \\
\text { fluids }\end{array}$ & (Ali et al. 2020) \\
\hline Lebanon & CTX-M & $\begin{array}{l}\text { Chicken and } \\
\text { soil }\end{array}$ & Feed sample and soil sample & (Dandachi et al. 2019) \\
\hline \multicolumn{5}{|c|}{ Proteus species } \\
\hline $\begin{array}{l}\text { Sudan } \\
\text { Enteroba }\end{array}$ & CTX-M & Human & Urine and wound swabs & (Musa et al. 2019) \\
\hline \multicolumn{4}{|c|}{ Klebsiella spp. } & (Hijazi et al. 1989) \\
\hline Egypt & CTX-M-15, CTX-M-27, CTX-M-14 & Human & $\begin{array}{l}\text { Lower respiratory tract specimens, urine and } \\
\text { pus or abdominal fluid of hospitalized patients } \\
\text { with lower respiratory tract infections (LRTI), } \\
\text { complicated urinary tract infections (cUTI), } \\
\text { and complicated intra-abdominal infections } \\
\text { (cIAI). }\end{array}$ & (El-kholy et al. 2020) \\
\hline Turkey & CTX-M & Human & Blood culture & (Midilli 2020) \\
\hline Iran & CTX & Human & Urine and sputum & (Malekjamshidi 2020) \\
\hline Palestine & CTX-M-15, and CTX-M-14 & Human & Urine, wound swabs, blood and ear discharge & (Tayh et al. 2020) \\
\hline Iran & CTX-M-1 & Human & Diarrheal samples & (Hajikarim et al. 2020) \\
\hline Iran & CTM-X & Human & (Unknown) clinical samples nine cities in Iran & (Armin et al. 2020) \\
\hline Yemen & CTX-M-15 & Human & $\begin{array}{l}\text { Aspiration, pus, blood, sputum, urine, ear } \\
\text { swab }\end{array}$ & (Alsharapy et al. 2019) \\
\hline Turkey & CTX-M & Human & $\begin{array}{l}\text { Catheter urine, Diabetic wound swab, sputum, } \\
\text { decubitus wound aspirate and abscess aspirate }\end{array}$ & (Evren et al. 2019) \\
\hline Egypt & $\begin{array}{l}\text { CTX-M-15, CTX-M-14, and CTX-M- } \\
9\end{array}$ & Human & $\begin{array}{l}\text { Ryle tube swab, blood, sputum, endotracheal } \\
\text { tube swab, ear swab, diabetic foot pus, eye } \\
\text { swab, urine, Cerebrospinal fluid, Ovarian cyst } \\
\text { abscess, left ureter, intraperitoneal fluid }\end{array}$ & (Nations et al. 2019) \\
\hline Egypt & CTX-M-9, and CTX-M-15 & Broiler farms & Cloacal swabs & (Moawad et al. 2018) \\
\hline KSA & CTX-M-15 & Human & Rectal swab & $\begin{array}{l}\text { (Aljindan et al. 2015; } \\
\text { Abdalhamid et al. 2016) }\end{array}$ \\
\hline Turkey & $\begin{array}{l}\text { (CTX-M-15 and CTXM-1) and CTX- } \\
\text { M-group2 }\end{array}$ & Human & Elderly male patient, urine, blood and wound & $\begin{array}{l}\text { (Elaldi et al. 2013; Görgeç et al. } \\
\text { 2015; Iraz et al. 2015) }\end{array}$ \\
\hline Kuwait & CTX-M-15, CTX-M-14 & Human & Urine, sputum and wound swab & (Jamal et al. 2015) \\
\hline
\end{tabular}


Table 1 (continued).

\begin{tabular}{|c|c|c|c|c|}
\hline \multicolumn{5}{|c|}{ CTX } \\
\hline Yemen & CTX-M-15 & human & $\begin{array}{l}\text { Urine, pus, blood, sputum, vaginal and ascites } \\
\text { fluid }\end{array}$ & (Gharout-Sait 2014) \\
\hline Egypt & CTX-M-15 & Cattle & Milk samples, rectal swabs and stalls & $\begin{array}{l}\text { (Hammad and Shimamoto } \\
\text { 2011; Braun et al. 2016) }\end{array}$ \\
\hline $\begin{array}{l}\text { United } \\
\text { Emirates }\end{array}$ & CTX-M-15 & Human & $\begin{array}{l}\text { Urine, blood, tracheal/bronchial aspirates, } \\
\text { wound swabs, sputum and ear discharges }\end{array}$ & (Alfaresi et al. 2011) \\
\hline Iran & $\begin{array}{l}\text { CTXM-1, CTXM-2, } \\
\text { CTXM-8 and CTXM-15 }\end{array}$ & Human & $\begin{array}{l}\text { Urine, trachea, wounds, blood, sputum, } \\
\text { hospitals in Tehran, respiratory and vaginal } \\
\text { secretions, ascites, biopsies, and body fluids, } \\
\text { Chronic obstructive pulmonary disease } \\
\text { (COPD) patients. }\end{array}$ & $\begin{array}{l}\text { (Feizabadi 2010; Peerayeh et } \\
\text { al. 2014; Bialvaei et al. 2016; } \\
\text { Akya et al. 2018; Dehshiri et } \\
\text { al. 2018) }\end{array}$ \\
\hline \multicolumn{5}{|l|}{ Salmonella spp } \\
\hline Saudi Arabia & CTX-M-1, CTX-M-9 & Human & Stool & (Desin 2019) \\
\hline Iran & CTX-M 1 /CTX-M-15 & Human & $\begin{array}{l}\text { Stool culture, blood culture, urine, sputum, } \\
\text { wound, respiratory and vaginal secretion, } \\
\text { ascites, biopsies, body fluids, diarrhea }\end{array}$ & $\begin{array}{l}\text { (Rizi et al. 2015; Bialvaei et } \\
\text { al. 2016; Aminshahidi et al. } \\
\text { 2017) }\end{array}$ \\
\hline Turkey & CTX-M-3 & Human & Neonate gastroenteritis & (Ăğın et al. 2014) \\
\hline \multicolumn{5}{|l|}{ Shigella spp. } \\
\hline Iran & CTX-M & Human & Stool sample & (Ghannadi and Ghane 2019) \\
\hline Iran & CTX-M-15 /CMY-2 & Human & $\begin{array}{l}\text { Stool culture, blood culture, urine, sputum, } \\
\text { wound, respiratory and vaginal secretion, } \\
\text { ascites, biopsies, body fluids, diarrhea }\end{array}$ & $\begin{array}{l}\text { (Rizi et al. 2015; Bialvaei et } \\
\text { al. 2016; Aminshahidi et al. } \\
\text { 2017) }\end{array}$ \\
\hline \multicolumn{5}{|c|}{ Enterobacter cloacae } \\
\hline Turkey & CTX-M & Human & Blood culture & (Midilli 2020) \\
\hline Lebanon & CTX-M & Soil & Soil sample & (Dandachi et al. 2019) \\
\hline Iran & CTX-M-15 & Human & $\begin{array}{l}\text { Urine, wound, sputum, broncho alveolar } \\
\text { lavage, trachea, blood and cerebrospinal fluid }\end{array}$ & (Peymani et al. 2014) \\
\hline \multicolumn{5}{|c|}{ a } \\
\hline Lebanon & $\begin{array}{l}\text { CTX-M-15, CTX-M-103 and CTX- } \\
\text { M-189 }\end{array}$ & Human & Rectal swabs from hospitalized patients & (Nawfal et al. 2020) \\
\hline Turkey & CTX-M & Human & Blood culture & (Midilli 2020) \\
\hline Palestine & CTX-M-15, and CTX-M-14 & Human & Urine, wound swabs, blood and ear discharge & (Tayh et al. 2020) \\
\hline Iran & CTM-X & Human & Unknown) clinical samples nine cities in Iran & (Armin et al. 2020) \\
\hline
\end{tabular}


Table 1 (continued).

\begin{tabular}{|c|c|c|c|c|}
\hline \multicolumn{5}{|c|}{ CTX } \\
\hline Egypt & CTX-M-28 & Raw beef & $\begin{array}{l}\text { Burgers, kofta (balls of } \\
\text { minced meat mixed with spices and onion), } \\
\text { and sausage sandwiches. }\end{array}$ & (Sabala et al. 2020) \\
\hline Egypt & CTX & $\begin{array}{l}\text { Chicken, } \\
\text { animal } \\
\text { human }\end{array}$ & $\begin{array}{l}\text { Retail chicken carcasses, ground beef, human } \\
\text { diarrheic patient }\end{array}$ & (Ramadan et al.) \\
\hline Tukey & CTX-M & Human & Urine & (Demirci-duarte et al. 2020) \\
\hline Egypt & CTX-M & Human & Urine & (Elshamy et al. 2020) \\
\hline Iran & CTX-M & Human & Kidney transplant patients & (Resistance et al. 2020b) \\
\hline Iran & CTX-M & Human & Urine & (Lesani et al. 2020) \\
\hline Egypt & CTX-M-15 & Human & Urine, stool, blood and wound swab samples & (Resistance et al. 2020a) \\
\hline Egypt. & $\begin{array}{l}\text { CTX-M-55, СТХ-M-15, CTX-M-27, } \\
\text { CTX-M-14 }\end{array}$ & Human & $\begin{array}{l}\text { lower respiratory tract specimens, urine and } \\
\text { pus or abdominal fluid of hospitalized patients } \\
\text { with lower respiratory tract infections (LRTI), } \\
\text { complicated urinary tract infections } \\
\text { (cUTI), andcomplicatedintra- } \\
\text { abdominalinfections(cIAI) }\end{array}$ & (El-kholy et al. 2020) \\
\hline Egypt & CTX-M & Human & Urine & (Hassuna et al. 2020) \\
\hline Turkey & $\begin{array}{l}\text { CTX-M-1, CTX-M-2, CTX-M-8/25 } \\
\text { and CTX-M-9 }\end{array}$ & Raw chicken & Meat & (Baran and Adiguzel 2020) \\
\hline Lebanon & CTX-M & Human & $\begin{array}{l}\text { Vaginal samples of pregnant women between } \\
35-37 \text { weeks of gestation }\end{array}$ & (Ghaddar et al. 2020) \\
\hline Saudi Arabia & CTX-M & Camel & Meat sample & (El-ghareeb et al. 2020) \\
\hline Saudi Arabia & CTX-M-15 and CTX-M-14 & Human & Blood & (Alqasim et al. 2019) \\
\hline Egypt. & $\begin{array}{l}\text { CTX-M-15, CTX-M-14, and CTX-M- } \\
9\end{array}$ & Human & $\begin{array}{l}\text { Ryle tube swab, blood, sputum, endotracheal } \\
\text { tube swab, ear swab, diabetic foot pus, eye } \\
\text { swab, urine, Cerebrospinal fluid, Ovarian cyst } \\
\text { abscess, left ureter, intraperitoneal fluid }\end{array}$ & (Nations et al. 2019) \\
\hline Yemen & CTX-M-15, CTX-M-216 & Human & Aspiration, pus and blood & (Alsharapy et al. 2019) \\
\hline Lebanon & CTX-M & $\begin{array}{l}\text { Chicken, } \\
\text { human and soil }\end{array}$ & $\begin{array}{l}\text { Chicken sample, farmer sample litter sample, } \\
\text { soil sample }\end{array}$ & (Dandachi et al. 2019) \\
\hline Iran & $\begin{array}{l}\text { CTX-M-3, CTX-M-8, CTX-M-2, and } \\
\text { CTX-M-25 }\end{array}$ & Human & urine & (City et al. 2019) \\
\hline Egypt & CTX-M-9, and CTX-M-15 & Broiler farms & Cloacal swabs & (Moawad et al. 2018) \\
\hline Lebanon & CTX-M & Swine farms & Fecal samples & (Dandachi et al. 2018a) \\
\hline
\end{tabular}


Table 1 (continued).

\begin{tabular}{|c|c|c|c|c|}
\hline \multicolumn{5}{|c|}{ CTX } \\
\hline Lebanon & CTX-M & Chicken farm & Rectal swab & (Dandachi et al. 2018) \\
\hline Lebanon & CTX-M & Human & Solid tumor and blood disorder & (Christophy et al. 2017) \\
\hline Egypt & blaCTX-M-14 & Chicken & Liver and heart & (El-Shazly et al. 2017) \\
\hline Turkey & CTX-M-15, CTX-M-3, CTX-M-1 & Dog & Rectal swabs from companion dogs & $\begin{array}{l}\text { (Aslantas and Yilmaz } \\
\text { 2017) }\end{array}$ \\
\hline Iran & CTX-M-15 & Human & Urine, wound swab, blood, and sputum & (Namaei 2017) \\
\hline Turkey & CTX-M-15 & $\begin{array}{l}\text { Bovine } \\
\text { mastitis }\end{array}$ & Milk samples & (Pehlivanoglu et al. 2016) \\
\hline Lebanon & CTX-M-15 & Cattle farm & Fecal samples & (Diab et al. 2016) \\
\hline KSA & CTX-M-15 & Human & Throat swabs, rectal swab & (Leangapichart, T. 2016) \\
\hline Jordan & CTX-M-15, CTX-M-2, and CTXM-1 & Human & Rectal samples & (Badran et al. 2016) \\
\hline Egypt & $\begin{array}{l}\text { CTX-M-variants (CTX-M-15, CTX- } \\
\text { M-104, CTX-M-3), TEM-52, SHV- } \\
\text { 12, and CMY-2 }\end{array}$ & $\begin{array}{l}\text { Chicken, beef } \\
\text { and dairy } \\
\text { products }\end{array}$ & $\begin{array}{l}\text { Meat, milk, cheese and yoghurt, Karish and } \\
\text { Ras cheeses }\end{array}$ & $\begin{array}{l}\text { (Ahmed and Shimamoto } \\
\text { 2015; Ombarak 2018) }\end{array}$ \\
\hline UAE & $\begin{array}{l}\text { CTX-M-15, CTX-M-3, and CTX-M- } \\
14\end{array}$ & Human & $\begin{array}{l}\text { Urine, blood, intra-abdominal specimens, } \\
\text { wound swabs respiratory specimens and } \\
\text { rectal swabs }\end{array}$ & (Peirano et al., 2014). \\
\hline Kuwait & $\begin{array}{l}\text { CTX-M-15, CTX-M-14, СТX-M-56, } \\
\text { and CTX-M-2 }\end{array}$ & Human & $\begin{array}{l}\text { (Unknown) patients in } 3 \text { hospitals, CSF, } \\
\text { Wound swab }\end{array}$ & $\begin{array}{l}\text { (Dashti et al. 2014; Jamal } \\
\text { et al. 2015) }\end{array}$ \\
\hline Palestine & $\begin{array}{l}\text { CTX-M (including CTX-M-1, CTX- } \\
\text { M-9) and SHV-12 }\end{array}$ & Chicken & Liver samples, carcasses & (Qabajah et al. 2014) \\
\hline Israel & $\begin{array}{l}\text { СТХ-M-27, СТХ-M-15, СТХ-M-14, } \\
\text { СТX-M-39, СТX-M-55 }\end{array}$ & Human & Rectal swab specimen & (Izdebski et al. 2013) \\
\hline Egypt & CTX-M-15, blaCMY-2 & $\begin{array}{l}\text { Poultry, } \\
\text { human }\end{array}$ & $\begin{array}{l}\text { Heart blood samples, carcasses, urine, } \\
\text { Sputum, pus samples }\end{array}$ & $\begin{array}{l}\text { (Ahmed et al. 2013; } \\
\text { Abdallah et al. 2015; } \\
\text { Ramadan et al. 2018) }\end{array}$ \\
\hline Egypt & CTX-M & pet dogs & Feces & (Aly et al. 2012) \\
\hline Egypt & CTX-M-15 & Cattle & Milk samples, rectal swabs and stalls & $\begin{array}{l}\text { (Hammad and Shimamoto } \\
\text { 2011; Braun et al. 2016) }\end{array}$ \\
\hline Turkey & $\begin{array}{l}\text { CTX-M-group1 (CTX-M-15 and } \\
\text { CTXM-1) and CTX-M-group2 }\end{array}$ & Human & & $\begin{array}{l}\text { (Elaldi et al. 2013; Görgeç } \\
\text { et al. 2015; Iraz et al. } \\
\text { 2015) }\end{array}$ \\
\hline $\begin{array}{l}\text { Pseudom } \\
\text { Yemen }\end{array}$ & CTX-M & Human & Burn wound swab. & (Nasser et al. 2020) \\
\hline Sudan & CTX-M-2 & Human & Wound swab, urine, and pleural fluid samples & (Babour et al. 2020) \\
\hline Iran & CTM-X & Human & Unknown) clinical samples nine cities in Iran & (Armin et al. 2020) \\
\hline Iran & CTX-M-1 & Human & Urine & (Hospitals et al. 2020) \\
\hline Lebanon & CTX-M & Chicken, soil & Feed sample, soil sample & (Dandachi et al. 2019) \\
\hline
\end{tabular}


Table 1 (continued).

\begin{tabular}{|c|c|c|c|c|}
\hline \multicolumn{5}{|c|}{ CTX } \\
\hline Egypt & $\begin{array}{l}\text { CTX-M-15, CTX-M-14, and CTX-M- } \\
9\end{array}$ & Human & $\begin{array}{l}\text { Ryle tube swab, blood, sputum, endotracheal } \\
\text { tube swab, ear swab, diabetic foot pus, eye } \\
\text { swab, urine, Cerebrospinal fluid, Ovarian cyst } \\
\text { abscess, left ureter, intraperitoneal fluid }\end{array}$ & (Nations et al. 2019) \\
\hline Iran & CTX-M & Human & Burn wound swabs & (Piri et al. 2018) \\
\hline Iran & CTX-M & Human & $\begin{array}{l}\text { Urine, blood, tracheal tube, wound, ear } \\
\text { discharge, wound infections, respiratory } \\
\text { infections, urinary tract infections, bed ulcer, } \\
\text { and burn }\end{array}$ & $\begin{array}{l}\text { (Fazeli and Momtaz } \\
\text { 2014; Rafiee et al. 2014; } \\
\text { Bokaeian et al. 2015) }\end{array}$ \\
\hline \multicolumn{5}{|c|}{ Serratia rubideae } \\
\hline Lebanon & CTX-M & chicken & Feed sample & (Dandachi et al., 2019) \\
\hline \multicolumn{5}{|c|}{ Serratia marcescens } \\
\hline Egypt & $\begin{array}{l}\text { CTX-M-15, CTX-M-14, and CTX-M- } \\
9\end{array}$ & Human & $\begin{array}{l}\text { Ryle tube swab, blood, sputum, endotracheal } \\
\text { tube swab, ear swab, diabetic foot pus, eye } \\
\text { swab, urine, Cerebrospinal fluid, Ovarian cyst } \\
\text { abscess, left ureter, intraperitoneal fluid }\end{array}$ & (Nations et al. 2019) \\
\hline \multicolumn{5}{|c|}{ Morganella morgana } \\
\hline Turkey & CTX-M & Human & Blood culture & (Midilli 2020) \\
\hline \multicolumn{5}{|c|}{ Enterobacter } \\
\hline Turkey & CTX-M & Human & $\begin{array}{l}\text { Unknown clinical specimen, wound infection, } \\
\text { Urine cultures }\end{array}$ & $\begin{array}{l}\text { (Nazik et al. 2011; } \\
\text { Nazipk et al. 2016; } \\
\text { Erdem, I. 2018) }\end{array}$ \\
\hline $\begin{array}{l}\text { Fecal car } \\
\text { Egypt }\end{array}$ & $\begin{array}{l}\text { CTX-M (CTXM-15, CTX-M-14, } \\
\text { CTX-M-2, and CTX-M-grp9) }\end{array}$ & Human & $\begin{array}{l}\text { Chest wound swab, central venous line, Rectal } \\
\text { swabs }\end{array}$ & $\begin{array}{l}\text { (Khalaf et al. 2009; Fam } \\
\text { et al. 2014) }\end{array}$ \\
\hline
\end{tabular}


Table 2 Epidemiology of beta lactamases resistance gene, TEM in Middle East

TEM

\begin{tabular}{|c|c|c|c|c|}
\hline \multicolumn{5}{|c|}{ TEM } \\
\hline $\begin{array}{l}\text { Klebsiella spp. } \\
\text { Lebanon }\end{array}$ & TEM-1, TEM-163 & Human & Rectal swab & (Nawfal et al. 2020) \\
\hline Egypt & $\begin{array}{l}\text { TEM-OSBL, } \\
\text { TEM-ESBL }\end{array}$ & Human & $\begin{array}{l}\text { Lower respiratory tract specimens, urine and pus or abdominal fluid of } \\
\text { hospitalized patients with lower respiratory tract infections (LRTI), } \\
\text { complicated urinary tract infections (cUTI), and complicated intra- } \\
\text { abdominal infections }\end{array}$ & (El-kholy et al. 2020) \\
\hline Iran & TEM & Human & Diarrheal samples & (Hajikarim et al. 2020) \\
\hline Palestine & TEM-1 & Human & Urine, wound swabs, blood and ear discharge & (Tayh et al. 2020) \\
\hline Iran & TEM & Human & Unknown) clinical samples nine cities in Iran & (Armin et al. 2020) \\
\hline Iran & TEM & Human & Urine and sputum & (Malekjamshidi 2020) \\
\hline Yemen & TEM-1 & Human & Aspiration, pus, sputum, urine & (Alsharapy et al. 2019) \\
\hline Iran & TEM genes & Human & Isolated from different sample, urine specimens & $\begin{array}{l}\text { (Gholipour et al. 2014; } \\
\text { Maleki 2018) }\end{array}$ \\
\hline \multicolumn{5}{|l|}{ E. coli } \\
\hline Lebanon & TEM-1, TEM-163 & Human & Rectal swab & (Nawfal et al. 2020) \\
\hline Egypt & $\begin{array}{l}\text { TEM-OSBL, } \\
\text { TEM-ESBL }\end{array}$ & Human & $\begin{array}{l}\text { Lower respiratory tract specimens, urine and pus or abdominal fluid of } \\
\text { hospitalized patients with lower respiratory tract infections (LRTI), } \\
\text { complicated urinary tract infections (cUTI), and complicated intra- } \\
\text { abdominal infections }\end{array}$ & (El-kholy et al. 2020) \\
\hline Lebanon & TEM & Human & Vaginal samples of pregnant women between 35-37 weeks & (Ghaddar et al. 2020) \\
\hline Iran & TEM & Human & Unknown) clinical samples nine cities in Iran & (Armin et al. 2020) \\
\hline Iran & TEM & Human & Urine & (Lesani et al. 2020) \\
\hline Iran & TEM & Human & Kidney transplant patients & (Resistance et al. 2020b) \\
\hline Egypt & $\begin{array}{l}\text { TEM-OSBL, } \\
\text { TEM-ESBL }\end{array}$ & Human & $\begin{array}{l}\text { Lower respiratory tract specimens, urine and pus or abdominal fluid of } \\
\text { hospitalized patients with lower respiratory tract infections (LRTI), } \\
\text { complicated urinary tract infections (cUTI), and complicated intra- } \\
\text { abdominal infections (cIAI) }\end{array}$ & (El-kholy et al. 2020) \\
\hline
\end{tabular}


Table 2 (continued).

\begin{tabular}{|c|c|c|c|c|}
\hline \multicolumn{5}{|c|}{ TEM } \\
\hline Egypt & TEM-116 & raw beef & $\begin{array}{l}\text { Burgers, kofta (balls of } \\
\text { minced meat mixed with spices and onion), and sausage sandwiches. }\end{array}$ & (Sabala et al. 2020) \\
\hline Egypt & TEM & Human & Urine & (Elshamy et al. 2020) \\
\hline Egypt & TEM & $\begin{array}{l}\text { Chicken, } \\
\text { animal } \\
\text { and } \\
\text { human }\end{array}$ & Retail chicken carcasses, ground beef, human diarrheic patient & (Ramadan et al.) \\
\hline Saudi Arabia & TEM & camel & Meat sample & (El-ghareeb et al. 2020) \\
\hline Egypt & TEM & Human & Urine & (Hassuna et al. 2020) \\
\hline Saudi Arabia & TEM & Human & Blood & (Alqasim et al. 2019) \\
\hline Egypt & TEM-1 & Human & Sputum, vaginal secretion, stool, urine, burn swab, wound swab & (Soliman et al. 2019) \\
\hline Yemen & TEM-1 & Human & Pus & (Alsharapy et al. 2019) \\
\hline Lebanon & TEM & $\begin{array}{l}\text { Chicken, } \\
\text { human } \\
\text { and soil }\end{array}$ & Chicken sample, farmer sample litter sample, soil sample & (Dandachi et al. 2019) \\
\hline Egypt & TEM & $\begin{array}{l}\text { broiler } \\
\text { farms }\end{array}$ & Cloacal swabs & (Moawad et al. 2018) \\
\hline Lebanon & TEM & $\begin{array}{l}\text { chicken } \\
\text { farm }\end{array}$ & Rectal swab & (Dandachi et al. 2018) \\
\hline Egypt & TEM & $\begin{array}{l}\text { poultry } \\
\text { hatcheries }\end{array}$ & Hatchling samples & (Osman et al. 2018) \\
\hline Egypt & TEM-57 & chicken & Liver and heart & (El-Shazly et al. 2017) \\
\hline Iran & TEM & Human & $\begin{array}{l}\text { Isolated from different sample, urine, blood, tracheal tube, ear discharge } \\
\text { sputum, wound, respiratory and vaginal secretion, ascites, biopsies, body } \\
\text { fluids }\end{array}$ & $\begin{array}{l}\text { (Gholipour et al. 2014; } \\
\text { Rezai et al. 2015; Shayan, } \\
\text { Bokaeian 2015; Bialvaei } \\
\text { et al. 2016) }\end{array}$ \\
\hline Iran & TEM & Human & Diarrheic pediatric patients, Diarrhea & $\begin{array}{l}\text { (Heidary and Madani } \\
\text { 2014; Aminshahidi et al. } \\
\text { 2017) }\end{array}$ \\
\hline Egypt & TEM-104 & Poultry & Heart blood samples, carcasses, urine, Sputum, pus samples & $\begin{array}{l}\text { (Ahmed et al. 2013; } \\
\text { Abdallah et al. 2015; } \\
\text { Ramadan et al. 2018) }\end{array}$ \\
\hline
\end{tabular}


Table 2 (continued).

\begin{tabular}{|c|c|c|c|c|}
\hline \multicolumn{5}{|c|}{ TEM } \\
\hline Egypt & TEM & Dog & Feces & (Aly et al. 2012) \\
\hline KSA & TEM & poultry & Meats, cloacal swabs & $\begin{array}{l}\text { (Altalhi and Gherbawy } \\
\text { 2010; Abo-amer et al. } \\
\text { 2018) }\end{array}$ \\
\hline \multicolumn{5}{|c|}{ Enterobacter } \\
\hline Iran & TEM & Human & (Unknown) clinical samples nine cities in Iran & (Armin et al. 2020) \\
\hline Iran & TEM-169 & Human & $\begin{array}{l}\text { Urine, wound, sputum, broncho alveolar lavage, trachea, blood and } \\
\text { cerebrospinal fluid }\end{array}$ & (Peymani et al. 2014) \\
\hline Turkey: & TEM & Human & (Unknown ) clinical spicemen, wound infection, Urine cultures & $\begin{array}{l}\text { (Nazik et al. 2011; Nazipk } \\
\text { et al. 2016; Erdem, I. } \\
\text { 2018) }\end{array}$ \\
\hline \multicolumn{5}{|c|}{ Pseudomonas } \\
\hline Yemen & TEM & Human & Burn wound swab & (Nasser et al. 2020) \\
\hline Sudan & TEM-1 & Human & Wound swab, urine, and pleural fluid & (Babour et al. 2020) \\
\hline Iran & TEM & Human & Unknown) clinical samples nine cities in Iran & (Armin et al. 2020) \\
\hline Lebanon & TEM & $\begin{array}{l}\text { Chicken, } \\
\text { soil }\end{array}$ & Feed sample, soil sample & (Dandachi et al. 2019) \\
\hline Iran & TEM-116 & Human & $\begin{array}{l}\text { Urine, blood, tracheal tube, wound, ear discharge, wound infections, } \\
\text { respiratory infections, urinary tract infections, bed ulcer, and burn }\end{array}$ & $\begin{array}{l}\text { (Fazelim, Momtaz 2014; } \\
\text { Rafiee et al. 2014; } \\
\text { Bokaeian et al. 2015) }\end{array}$ \\
\hline \multicolumn{5}{|c|}{ Shigella spp } \\
\hline Iran & TEM & Human & Stool sample & $\begin{array}{l}\text { (Ghannadi and Ghane } \\
\text { 2019) }\end{array}$ \\
\hline \multicolumn{5}{|c|}{ Acinetobacter baumannii } \\
\hline Iran & TEM & Human & Unknown) clinical samples nine cities in Iran & (Armin et al. 2020) \\
\hline Lebanon & TEM & $\begin{array}{l}\text { Chicken } \\
\text { and soil }\end{array}$ & Feed sample and soil sample & (Dandachi et al. 2019) \\
\hline \multicolumn{5}{|c|}{ Stenotrophomonas maltophilia } \\
\hline Lebanon & TEM & Soil & Soil sample & (Dandachi et al. 2019) \\
\hline
\end{tabular}


Table 2 (continued).

\begin{tabular}{|c|c|c|c|c|}
\hline \multicolumn{5}{|c|}{ TEM } \\
\hline \multicolumn{5}{|l|}{ Proteus spp } \\
\hline Sudan & TEM & Human & Urine and wound swabs & (Musa et al. 2019) \\
\hline \multicolumn{5}{|c|}{ Enterobacter cloacae } \\
\hline $\begin{array}{l}\text { Lebanon } \\
\text { Fecal carriag }\end{array}$ & TEM & Soil & Soil sample & (Dandachi et al. 2019) \\
\hline Egypt & TEM & Human & Chest wound swab, central venous line, Rectal swabs & $\begin{array}{l}\text { (Khalaf et al. 2009; Fam et } \\
\text { al. 2014) }\end{array}$ \\
\hline \multicolumn{5}{|l|}{ Salmonella } \\
\hline Saudi Arabia & TEM-1 & Human & Stool, urine, tissue, abdominal fluid, wound and blood & (Desin 2019) \\
\hline Kuwait & TEM-1 & Human & Blood & (Albert et al. 2019) \\
\hline Egypt & TEM & $\begin{array}{l}\text { chicken } \\
\text { and } \\
\text { pigeons }\end{array}$ & Chicken breast meat fillet without skin, cloacal swabs & $\begin{array}{l}\text { (Ahmed et al. 2016; } \\
\text { Abdeen et al. 2018) }\end{array}$ \\
\hline
\end{tabular}


Table 3 Epidemiology of beta lactamases resistance gene, SHV in Middle East

\begin{tabular}{|c|c|c|c|c|}
\hline \multicolumn{5}{|c|}{ SHV } \\
\hline E. coli & & & & \\
\hline Egypt & SHV & Human & Urine & (Hassuna et al. 2020) \\
\hline Saudi Arabia & SHV & camel & Meat sample & (El-ghareeb et al. 2020) \\
\hline Lebanon & SHV & Human & Vaginal samples of pregnant women between 35-37 weeks & (Ghaddar et al. 2020) \\
\hline Egypt & $\begin{array}{l}\text { SHV-OSBL, } \\
\text { SHV-12 }\end{array}$ & Human & $\begin{array}{l}\text { Lower respiratory tract specimens, urine and pus or abdominal } \\
\text { fluid of hospitalized patients with lower respiratory tract } \\
\text { infections (LRTI), complicated urinary tract infections } \\
\text { (cUTI), and complicated intra-abdominal infections (cIAI) }\end{array}$ & (El-kholy et al. 2020) \\
\hline Iran. & SHV & Human & Kidney transplant patients & (Resistance et al. 2020b) \\
\hline Egypt & SHV & Human & Urine & (Elshamy et al. 2020) \\
\hline Egypt & SHV & $\begin{array}{l}\text { Chicken, } \\
\text { animal } \\
\text { and } \\
\text { human }\end{array}$ & Retail chicken carcasses, ground beef, human diarrheic patient & (Ramadan et al.) \\
\hline Iran & SHV & Human & Unknown) clinical samples nine cities in Iran & (Armin et al. 2020) \\
\hline Iran & SHV & Human & Urine & (Lesani et al. 2020) \\
\hline Egypt. & $\begin{array}{l}\text { SHV-142, } \\
\text { SHV-28, SHV- } \\
11, \quad \text { SHV-27, } \\
\text { SHV-71, SHV- } \\
63 \text { SHV-82, } \\
\text { SHV-33, and } \\
\text { SHV-2 }\end{array}$ & Human & $\begin{array}{l}\text { Blood, urine, sputum, eye swab, pus, diabetic foot pus, } \\
\text { endotracheal tube swab, peritoneal swab, ear swab, } \\
\text { cerebrospinal fluid }\end{array}$ & (Nations et al. 2019) \\
\hline $\begin{array}{l}\text { United Arab } \\
\text { Emirate }\end{array}$ & $\begin{array}{l}\text { SHV-12, SHV- } \\
11\end{array}$ & Human & Urine, Wound, Blood & (Pál and Sonnevend 2019) \\
\hline Lebanon & SHV & $\begin{array}{l}\text { Chicken, } \\
\text { human } \\
\text { and soil }\end{array}$ & Chicken sample, farmer sample litter sample, soil sample & (Dandachi et al. 2019) \\
\hline
\end{tabular}


Table 3 (continued).

\begin{tabular}{|c|c|c|c|c|c|}
\hline \multicolumn{6}{|c|}{ SHV } \\
\hline Iran & SHV & & $\begin{array}{l}\text { Milk and } \\
\text { dairy } \\
\text { products }\end{array}$ & $\begin{array}{l}\text { Raw bovine, raw ovine, raw caprine, raw buffalo and raw } \\
\text { camel milk samples and traditional cheese, yoghurt, kashk, } \\
\text { dough, butter, cream and ice-cream }\end{array}$ & (Ranjbar et al. 2018) \\
\hline Egypt & SHV & & $\begin{array}{l}\text { Broiler } \\
\text { farms. }\end{array}$ & Cloacal swabs & (Moawad et al. 2018) \\
\hline Egypt & SHV & & $\begin{array}{l}\text { poultry } \\
\text { hatcheries }\end{array}$ & Hatchling samples & (Osman et al. 2018) \\
\hline Egypt & SHV-12 & & Chicken & Liver and heart & (El-Shazly et al. 2017) \\
\hline Turkey & SHV-12 & & Dog & Rectal swabs from companion dogs & (Aslantas and Yilmaz 2017) \\
\hline Egypt & SHV-12 & & $\begin{array}{l}\text { Chicken, } \\
\text { beef and } \\
\text { dairy } \\
\text { products }\end{array}$ & Meat, milk, cheese and yoghurt, Karish and Ras cheeses & $\begin{array}{l}\text { (Ahmed and Shimamoto 2015; } \\
\text { Ombarak 2018) }\end{array}$ \\
\hline Palestine & SHV-12 & & Chicken & Liver samples, carcasses & (Qabajah et al. 2014) \\
\hline Iran & SHV & & Human & $\begin{array}{l}\text { Isolated from different sample, urine, blood, tracheal } \\
\text { tube,ear discharge sputum, wound, respiratory and vaginal } \\
\text { secretion, ascites, biopsies, body fluids }\end{array}$ & $\begin{array}{l}\text { (Gholipour et al. 2014; Rezai et al. 2015; } \\
\text { Shayan and Bokaeian 2015; Bialvaei et } \\
\text { al. 2016) }\end{array}$ \\
\hline Lebanon & SHV-5a & & Human & $\begin{array}{l}\text { Urine, respiratory tract, pus, digestive tract, blood, } \\
\text { nasopharynx, sputum }\end{array}$ & (Charrouf et al. 2014; Daoud et al. 2017) \\
\hline Kuwait & SHV-12 & & Human & (Unknown) patients in 3 hospitals, CSF, Wound swab & (Dashti et al. 2014; Jamal et al. 2015) \\
\hline Israel & $\begin{array}{l}\text { SHV-5, } \\
12\end{array}$ & SHV- & Human & Rectal swab specimen & (Izdebski et al. 2013) \\
\hline Egypt & SHV & & Dog & Feces & (Aly et al. 2012) \\
\hline Egypt & SHV-12 & & Human & $\begin{array}{l}\text { Urine, stool, sterile sites, blood, catheter tips, cerebrospinal } \\
\text { fluid, ear discharge, endotracheal Tubing, midline } \\
\text { subumbilical gaps, peritoneal discharge, pus, sputum, and } \\
\text { wounds }\end{array}$ & $\begin{array}{l}\text { (Hassan et al. 2012; Abdelaziz et al. } \\
\text { 2013; Abdallah et al. 2015; Helmy, and } \\
\text { Kashef 2017) }\end{array}$ \\
\hline $\mathrm{KSA}$ & $\begin{array}{l}\text { SHV-12, } \\
\text { SHV-5 }\end{array}$ & and & Human & $\begin{array}{l}\text { Hospitalized patient (different sites), urine, blood, wounds, } \\
\text { sputum, and other body fluid, urine catheters }\end{array}$ & $\begin{array}{l}\text { (Shibl et al. 2012; Sheikh et al. 2014; } \\
\text { Alyamani et al. 2017; Yasir et al. 2018) }\end{array}$ \\
\hline KSA & SHV & & Poultry & Meats, cloacal swabs & $\begin{array}{l}\text { (Altalhi et al. 2010; Abo-amer et al. } \\
\text { 2018) }\end{array}$ \\
\hline
\end{tabular}


Table 3 (continued).

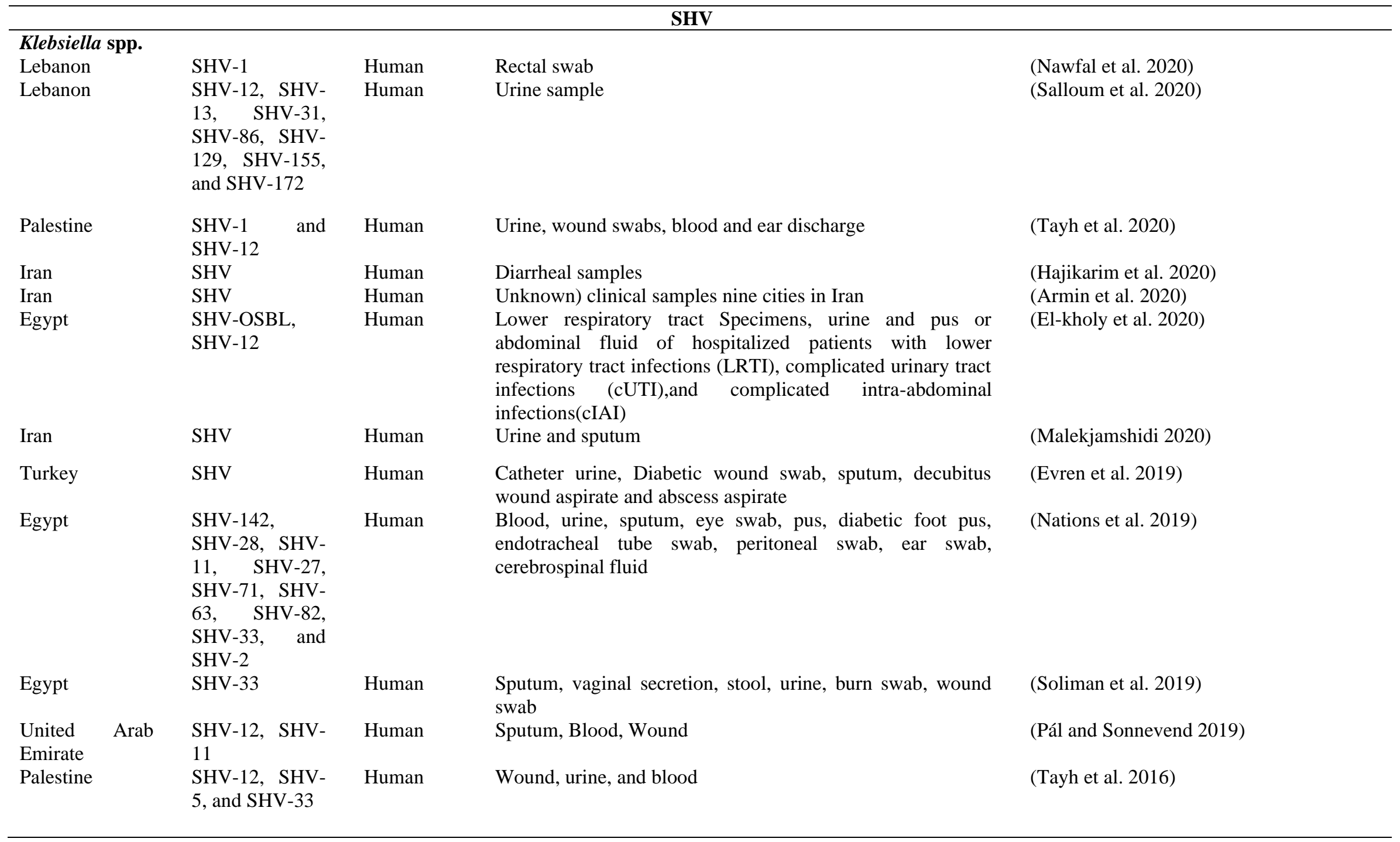


Table 3 (continued).

\begin{tabular}{|c|c|c|c|c|c|}
\hline \multicolumn{6}{|c|}{ SHV } \\
\hline Kuwait & & SHV-11 & Human & Urine, sputum and wound swab & (Jamal et al. 2015) \\
\hline Yemen & & $\begin{array}{ll}\text { SHV-11, } & \text { SHV- } \\
76, \text { and SHV- } \\
184\end{array}$ & Human & Urine, pus, blood, sputum, vaginal and ascites fluid & (Gharout-Sait 2014) \\
\hline Lebanon & & SHV-5a & Human & $\begin{array}{l}\text { Urine, respiratory tract, pus, digestive tract, blood, } \\
\text { nasopharynx, sputum }\end{array}$ & (Charrouf et al. 2014; Daoud et al. 2017) \\
\hline Egypt & & SHV-28 & bovine & Milk samples & (Hammad, Shimamoto 2011) \\
\hline $\begin{array}{l}\text { United } \\
\text { Emirates }\end{array}$ & Arab & SHV-258 & Human & $\begin{array}{l}\text { Urine, blood, tracheal/bronchial aspirates, wound swabs, } \\
\text { sputum and ear discharges }\end{array}$ & (Alfaresi et al. 2011) \\
\hline Iran & & $\begin{array}{l}\text { SHV (SHV-12, } \\
\text { SHV-11, SHV- } \\
5)\end{array}$ & Human & Urine, trachea, wounds, blood, sputum & $\begin{array}{l}\text { (Feizabadi, M. M. 2010; Shakib, P. } \\
\text { 2018) }\end{array}$ \\
\hline \multicolumn{6}{|c|}{ Enterobacter } \\
\hline Lebanon & & SHV & Soil & Soil sample & (Dandachi et al. 2019) \\
\hline Iran & & SHV & Human & Unknown) clinical samples nine cities in Iran & (Armin et al. 2020) \\
\hline KSA & & SHV-5 & Human & Wound, blood, respiratory and urinary tract specimen & (Abdalhamid et al. 2017) \\
\hline Iran & & SHV-12 & Human & $\begin{array}{l}\text { Urine, wound, sputum, broncho alveolar lavage, trachea, } \\
\text { blood and cerebrospinal fluid }\end{array}$ & (Peymani et al. 2014) \\
\hline Kuwait & & SHV-112 & Human & blood and urine & (Dashti et al. 2013) \\
\hline Turkey & & SHV & Human & $\begin{array}{l}\text { (Unknown ) clinical spicemen, wound infection, Urine } \\
\text { cultures }\end{array}$ & $\begin{array}{l}\text { (Nazik et al. 2011; Nazipk et al. 2016; } \\
\text { Erdem, I. 2018) }\end{array}$ \\
\hline \multicolumn{6}{|c|}{ Stenotrophomonas maltophilia } \\
\hline Lebanon & & SHV & soil & Soil sample & (Dandachi et al. 2019) \\
\hline
\end{tabular}


Table 3 (continued).

\begin{tabular}{|c|c|c|c|c|}
\hline \multicolumn{5}{|c|}{ SHV } \\
\hline \multicolumn{5}{|c|}{ Citrobacter freundii. } \\
\hline $\begin{array}{l}\text { United Arab } \\
\text { Emirate }\end{array}$ & $\begin{array}{l}\text { SHV-12, SHV- } \\
11\end{array}$ & Human & Urine & (Pál, Sonnevend 2019) \\
\hline \multicolumn{5}{|l|}{ Pseudomonas } \\
\hline Yemen & SHV & Human & Burn wound swab & (Nasser et al. 2020) \\
\hline Iran & SHV & Human & Unknown) clinical samples nine cities in Iran & (Armin et al. 2020) \\
\hline Sudan. & SHV-1 & Human & Wound swab, urine, and pleural fluid samples & (Babour et al. 2020) \\
\hline Egypt & $\begin{array}{l}: \text { SHV-142, } \\
\text { SHV-28, SHV- } \\
11, \quad \text { SHV-27, } \\
\text { SHV-71, SHV- } \\
63, \quad \text { SHV-82, } \\
\text { SHV-33, and } \\
\text { SHV-2 }\end{array}$ & Human & $\begin{array}{l}\text { Blood, urine, sputum, eye swab, pus, diabetic foot pus, } \\
\text { endotracheal tube swab, peritoneal swab, ear swab, } \\
\text { cerebrospinal fluid }\end{array}$ & (Nations et al. 2019) \\
\hline Iran & SHV-12 & Human & $\begin{array}{l}\text { Urine, blood, tracheal tube, wound, ear discharge, wound } \\
\text { infections, respiratory infections, urinary tract infections, } \\
\text { bed ulcer, and burn }\end{array}$ & $\begin{array}{l}\text { (Fazeli and Momtaz 2014; Rafiee et al. } \\
\text { 2014; Bokaeian et al. 2015) }\end{array}$ \\
\hline \multicolumn{5}{|l|}{ Fecal carriage } \\
\hline Egypt & TEM & Human & Chest wound swab, central venous line, Rectal swabs & (Khalaf et al. 2009; Fam et al. 2014) \\
\hline \multicolumn{5}{|l|}{ Salmonella } \\
\hline Turkey & SHV-12 & Human & Neonate gastroenteritis & (Ağın et al. 2014) \\
\hline
\end{tabular}


Table 4 Epidemiology of beta lactamases resistance gene, OXA in Middle East.

\begin{tabular}{|c|c|c|c|c|}
\hline \multicolumn{5}{|c|}{ OXA } \\
\hline \multicolumn{5}{|l|}{ Pseudomonas } \\
\hline Yemen & OXA-10 & Human & From burn wound swab & (Nasser et al. 2020) \\
\hline Saudi Arabia & OXA-48 & Human & $\begin{array}{l}\text { Blood, Pus, Stool, Urine, Sputum, Endotracheal tube, Vaginal swab, } \\
\text { Peritoneal fluid }\end{array}$ & (Khan et al.) \\
\hline Turkey & $\begin{array}{l}\text { OXA-10, } \\
\text { OXA-14 }\end{array}$ & Human & $\begin{array}{l}\text { Urine, blood, sputum, bronchoalveolar lavage, abscess, wound swabs, } \\
\text { endotracheal aspirate, throat swabs, catheter tips, one of each pleural } \\
\text { and peritoneal fluid }\end{array}$ & (Aktas 2012; Er et al. 2015) \\
\hline KSA & OXA-10 & Human & Burn, sputum, pus, urine, Eye discharge, Blood & $\begin{array}{l}\text { (Al-agamy et al. 2012; Tawfik } \\
\text { et al. 2012) }\end{array}$ \\
\hline Iran & $\begin{array}{l}\text { OXA- } \\
10 / O X A-4\end{array}$ & Human & $\begin{array}{l}\text { Burn wounds, Trashes, Urine, Blood, Feces, Sputum, CSF, trachea, } \\
\text { blood cultures, lesion and sputum, bronchoalveolar lavage, trachea }\end{array}$ & $\begin{array}{l}\text { Mirsalehian et al. 2010; } \\
\text { Alikhani et al. 2014; } \\
\text { Farshadzadeh, Dokht 2014; } \\
\text { Emami et al. 2015; Davodian, } \\
\text { et al. 2016; Amirkamali et al. } \\
\text { 2017) }\end{array}$ \\
\hline \multicolumn{5}{|l|}{ E. coli } \\
\hline Egypt & $\begin{array}{l}\text { OXA- } 48 \\
\text { OXA-181 } \\
\text { OXA-244 }\end{array}$ & Human & $\begin{array}{l}\text { Lower respiratory tract specimens, urine and pus or abdominal fluid of } \\
\text { hospitalized patients with lower respiratory tract infections (LRTI), } \\
\text { complicated urinary tract infections (cUTI), and complicated intra- } \\
\text { abdominal infections (cIAI) }\end{array}$ & (El-kholy et al. 2020) \\
\hline Egypt & $\begin{array}{l}\text { OXA-2, } \\
\text { OXA-10 }\end{array}$ & Human & Urine, blood and wound swab & (Resistance et al. 2020a) \\
\hline Turkey & OXA-48 & Human & Blood culture & (Midilli 2020) \\
\hline Saudi Arabia & OXA & Human & Blood & (Alqasim et al. 2019) \\
\hline Egypt & OXA & human & Diarrheic patient & (Ramadan et al.) \\
\hline Yemen & $\begin{array}{l}\text { OXA-48 } \\
\text {,OXA-181 }\end{array}$ & Human & Urine ,aspiration & (Alsharapy et al. 2019) \\
\hline Egypt & $\begin{array}{l}\text { OXA-181, } \\
\text { OXA-1 }\end{array}$ & Human & Sputum, vaginal secretion, stool, urine, burn swab, wound swab & (Soliman et al. 2019) \\
\hline
\end{tabular}


Table 4 (continued).

\begin{tabular}{|c|c|c|c|c|}
\hline \multicolumn{5}{|c|}{ OXA } \\
\hline $\begin{array}{l}\text { United Arab } \\
\text { Emirate }\end{array}$ & OXA-181 & Human & Urine and rectal swab & (Pál, Sonnevend 2019) \\
\hline Saudi Arabia & OXA-48 & & $\begin{array}{l}\text { Blood, Pus, Stool, Urine, Sputum, Endotracheal tube, Vaginal swab, } \\
\text { Peritoneal fluid }\end{array}$ & (Khan et al.) \\
\hline Egypt & OXA-7 & broiler farms & Cloacal swabs & (Moawad et al. 2018) \\
\hline Egypt & OXA-30 & Poultry & Heart blood samples, carcasses, urine, Sputum, pus samples & $\begin{array}{l}\text { (Ahmed et al. 2013; Abdallah } \\
\text { et al. 2015; Ramadan et al. } \\
\text { 2018) }\end{array}$ \\
\hline Turkey: & OXA-10 & Human & Elderly male patient, urine, blood and wound & $\begin{array}{l}\text { (Elaldi et al. 2013; Görgeç et } \\
\text { al. 2015; Iraz et al. 2015) }\end{array}$ \\
\hline \multicolumn{5}{|l|}{ Klebsiella } \\
\hline Egypt & $\begin{array}{l}\text { OXA- } 48 \\
\text { OXA-181 } \\
\text { OXA-232 }\end{array}$ & Human & $\begin{array}{l}\text { Lower respiratory tract specimens, urine and pus or abdominal fluid of } \\
\text { hospitalized patients with lower respiratory tract infections (LRTI), } \\
\text { complicated urinary tract infections (cUTI), and complicated intra- } \\
\text { abdominal infections (cIAI) }\end{array}$ & (El-kholy et al. 2020) \\
\hline Palestine & OXA-1 & Human & From urine, wound swabs, blood and ear discharge & (Tayh et al. 2020) \\
\hline Turkey & OXA-48 & Human & Blood culture & (Midilli 2020) \\
\hline Yemen & $\begin{array}{l}\text { OXA-48, } \\
\text { OXA-232 }\end{array}$ & Human & Ear swab and pus, Sputum & (Alsharapy et al. 2019) \\
\hline $\begin{array}{l}\text { United Arab } \\
\text { Emirates: }\end{array}$ & OXA-48 & Human & Rectal swab & (Moubareck et al. 2019) \\
\hline Saudi Arabia & OXA-48 & Human & $\begin{array}{l}\text { Blood, Pus, Stool, Urine, Sputum, Endotracheal tube, Vaginal swab, } \\
\text { Peritoneal fluid }\end{array}$ & (Khan et al.) \\
\hline $\begin{array}{l}\text { United Arab } \\
\text { Emirate }\end{array}$ & OXA-181 & Human & Blood and rectal swab & (Pál, Sonnevend 2019) \\
\hline Egypt & OXA-10 & Bovine & Milk samples & $\begin{array}{l}\text { (Hammad and Shimamoto } \\
\text { 2011) }\end{array}$ \\
\hline \multicolumn{5}{|c|}{ Acinetobacter baumannii } \\
\hline Iran & OXA -23 & Human & $\begin{array}{l}\text { Blood, tracheal aspirate, bronchial washing, sputum, abscess, wound, } \\
\text { catheter, ascitic fluid and urine }\end{array}$ & (Rahbarnia et al. 2019) \\
\hline
\end{tabular}


Table 4 (continued).

\begin{tabular}{|c|c|c|c|c|}
\hline \multicolumn{5}{|c|}{ OXA } \\
\hline Egypt & $\begin{array}{l}\text { OXA } 51, \\
\text { OXA-23 and } \\
\text { OXA-143 }\end{array}$ & Human & Wound, Burns, buccal cavity, skin and eye swabs & (El-baky et al. 2020) \\
\hline \multicolumn{5}{|c|}{ Enterobacter cloacae } \\
\hline Saudi Arabia & OXA-48 & Human & $\begin{array}{l}\text { Blood, Pus, Stool, Urine, Sputum, Endotracheal tube, Vaginal swab, } \\
\text { Peritoneal fluid }\end{array}$ & (Khan et al.) \\
\hline Turkey & OXA-48 & Human & Blood culture & . (Midilli 2020) \\
\hline Yemen & OXA-181 & Human & Urine & (Alsharapy et al. 2019) \\
\hline \multicolumn{5}{|c|}{ Morganella morgani } \\
\hline Turkey & OXA-48 & Human & Blood culture & (Midilli 2020) \\
\hline \multicolumn{5}{|c|}{ Salmonella spp } \\
\hline Saudi Arabia & $\begin{array}{l}\text { OXA-1 and } \\
\text { OXA-48 }\end{array}$ & Human & stool and wound & (Desin 2019) \\
\hline
\end{tabular}

Table 5 Epidemiology of beta lactamases resistance gene, CMY in Middle East

\begin{tabular}{|c|c|c|c|c|}
\hline \multicolumn{5}{|c|}{ CMY } \\
\hline \multicolumn{5}{|l|}{ Shigella } \\
\hline Iran & CMY-2 & Human & $\begin{array}{l}\text { Stool culture, blood culture, urine, sputum, wound, respiratory } \\
\text { and vaginal secretion, ascites, biopsies, body fluids, diarrhea }\end{array}$ & $\begin{array}{l}\text { (Rizi et al. 2015; Bialvaei et } \\
\text { al. 2016; Aminshahidi et al. } \\
\text { 2017) }\end{array}$ \\
\hline Israel & $\begin{array}{l}\text { CMY-4 and } \\
\text { CMY-2 }\end{array}$ & Human & Rectal swab specimen & (Izdebski et al. 2013) \\
\hline \multicolumn{5}{|l|}{ E. coli } \\
\hline Egypt & $\begin{array}{l}\text { CMY-2, } \\
\text { CMY, CMY- } \\
\text { TYPE, CMY- } \\
4, \quad \text { CMY4-2 } \\
\text { and CMY-59 }\end{array}$ & Human & $\begin{array}{l}\text { Lower respiratory tract specimens, urine and pus or abdominal } \\
\text { fluid of hospitalized patients with lower respiratory tract } \\
\text { infections (LRTI), complicated urinary tract infections } \\
\text { (cUTI), and complicated intra-abdominal infections (cIAI) }\end{array}$ & (El-kholy et al. 2020) \\
\hline Egypt & $\begin{array}{l}\text { CMY-6, } \\
\text { CMY-42, } \\
\text { CMY-72 like, } \\
\text { and CMY-2 }\end{array}$ & Human & Eye swab, urine, intraperitoneal fluid, pus swab, and blood & (Nations et al. 2019) \\
\hline Egypt & CMY 2 & Human & Sputum, vaginal secretion, stool, urine, burn swab, wound swab & (Soliman et al. 2019) \\
\hline Lebanon & CMY & Swine farms & Fecal samples & (Dandachi et al. 2018a) \\
\hline Lebanon & CMY & Farm chicken & Rectal swab & (Dandachi et al. 2018) \\
\hline Egypt & CMY-2 & Broiler farms. & Cloacal swabs & (Moawad et al. 2018) \\
\hline
\end{tabular}




\section{Table 5 (continued).}

\begin{tabular}{|c|c|c|c|c|}
\hline \multicolumn{5}{|c|}{ CMY } \\
\hline Turkey & CMY-2 & Dog & Rectal swabs from companion dogs & (Aslantas and Yilmaz 2017) \\
\hline Egypt & CMY-2 & $\begin{array}{l}\text { Chicken, beef and } \\
\text { dairy products }\end{array}$ & Meat, milk, cheese and yoghurt, Karish and Ras cheeses & $\begin{array}{l}\text { (Ahmed, Shimamoto 2015; } \\
\text { Ombarak 2018) }\end{array}$ \\
\hline Kuwait & CMY-2 & Human & (Unknown) patients in 3 hospitals, CSF, Wound swab & $\begin{array}{l}\text { (Dashti et al. 2014; Jamal et } \\
\text { al. 2015) }\end{array}$ \\
\hline Egypt & CMY-2 & Poultry & Heart blood samples, carcasses, urine, Sputum, pus samples & $\begin{array}{l}\text { (Ahmed et al. 2013; Abdallah } \\
\text { et al. 2015; Ramadan, H. H., } \\
\text { Jackson et al. 2018) }\end{array}$ \\
\hline Israel & $\begin{array}{l}\text { CMY-4 and } \\
\text { CMY-2 }\end{array}$ & Human & Rectal swab specimen & (Izdebski et al. 2013) \\
\hline Turkey & CMY-2 & Human & Urine, Blood & $\begin{array}{l}\text { (Demirbakan, H. 2008; Sari et } \\
\text { al. 2013; Yilmaz et al. 2013) }\end{array}$ \\
\hline \multicolumn{5}{|l|}{ Enterobacter } \\
\hline KSA & CMY-2 & Human & Wound, blood, respiratory and urinary tract specimen & (Abdalhamid et al. 2017) \\
\hline \multicolumn{5}{|c|}{ Klebsiella pneumoniae } \\
\hline Egypt & $\begin{array}{l}\text { CMY-6, } \\
\text { CMY-42, } \\
\text { CMY-72 like, } \\
\text { and CMY-2 }\end{array}$ & Human & Eye swab, urine, intraperitoneal fluid, pus swab, and blood & (Nations et al. 2019) \\
\hline \multicolumn{5}{|l|}{ Salmonella } \\
\hline Saudi Arabia & $\mathrm{CMY}-2$ & Human & Stool and wound & (Desin 2019) \\
\hline Egypt & blaCMY-2 & Dairy calves & Diarrheic neonatal calves & (Ahmed et al. 2009) \\
\hline
\end{tabular}


Ahmad H P, Khalil M K (2019) Prevalence of blaTEM, blaSHV, and blaCTX-M Genes among ESBLProducing Klebsiella pneumoniae and Escherichia

coli isolated from Thalassemia patients in Erbil, Iraq. Mediterr J Hematol Infect Dis 1-7.

Ahmed AM, Shimamoto T (2015) Molecular analysis of multidrug resistance in Shiga toxin-producing Escherichia coli $\mathrm{O} 157$ : $\mathrm{H} 7$ isolated from meat and dairy products. Int J Food Microbiol 193:68-73. doi: 10.1016/j.ijfoodmicro.2014.10.014

Ahmed AM, Shimamoto T, Shimamoto T (2013) Molecular characterization of multidrug-resistant avian pathogenic Escherichia coli isolated from septicemic broilers. Int J Med Microbiol. 303:475483 doi:10.1016/j.ijmm.2013.06.009

Ahmed AM, Younis EEA, Osman SA, et al (2009) Genetic analysis of antimicrobial resistance in Escherichia coli isolated from diarrheic neonatal calves. Veterinary Microbiology 136(3-4):397-402.

Ahmed HA, El-hofy FI, Al AET (2016) Characterization of virulence-associated genes, antimicrobial resistance genes, and class 1 Integrons in Salmonella enterica serovar Typhimurium isolates from chicken meat and humans in Egypt.Foodborne Pathogenes and Disease 13(6):281-288 doi: 10.1089/fpd.2015.2097

Ahmed M, Soliman AM, Zarad HO, Nariya H, et al (2019) Genetic analysis of carbapenemaseproducing Gram-negative bacteria isolated from a university teaching hospital in Egypt. Jo ur na $1 \mathrm{P}$. Infect Genet Evol 104065. doi: 10.1016/j.meegid.2019.104065

Aktas Z et al. (2012) Antibiotic susceptibility rates and beta-lactam resistance mechanisms of Pseudomonas aeruginosa strains. Mikrobiyol Bul 46:386-397

Aktas Z, Poirel L, Slciog lu M, O” zcan PE, Midilli K, Bal C, Ang O", Nordmann P (2005) PER-1- and OXA10-like b-lactamases in ceftazidime-resistant Pseudomonas aeruginosa isolates from intensive care unit patients in Istanbul, Turkey. Clin Microbiol Infect 11: 193-198.

Alaa AR, Solhan MA, Lalan RM, Hiwa LI, Mhamad NR, Niga KH, Awat JN, Salar AI, Brwa HR, Daryan K KH, Taib AH (2020) The Antibiotic resistance Pattern and Molecular Characterization of bla CTX and bla TEM genes of $E$. coli isolated from different hosts based on the rate of antibiotic consumption in Sulaymaniyah/Iraq. Appl Ecol Environ Res 18(5)6025-6040 18:6025-6040.

Al-agamy MH, Shibl AM, Tawfik AF, et al (2012) Extended-spectrum and metallo-beta-lactamases among ceftazidime-resistant Pseudomonas aeruginosa in Riyadh, Saudi Arabia. Journal of Chemotherapy 24(2);97-100. doi:

\subsection{9/1120009X12Z.00000000015}

Albert MJ, Bulach D, Alfouzan W, et al (2019) Nontyphoid Salmonella blood stream infection in Kuwait: Clinical and microbiological characteristics. 1-21

Alcantar-curiel D, Tinoco JC, Gayosso C, et al (2004) Nosocomial bacteremia and urinary tract infections caused by extended-spectrum b -Lactamase producing Klebsiella pneumoniae with Plasmids Carrying Both SHV-5 and TLA-1 Genes. Clin Infect Dis. 1067-1074

Alfaresi, M. S., Elkoush, A. A., Alshehhi, H. M., and Abdulsalam AI (2011) Molecular characterization and epidemiology of Escherichia coli and Klebsiella pneumoniae isolates in the United Arab Emirates. Medical Principles and Practice 20(2):177-180. doi: 10.1159/000319912

Ali J, Rafiq QA, Ratcliffe E (2018) Antimicrobial resistance mechanisms and potential synthetic treatments. J Future Science OA (4):FSO290

Ali M, Shahraki-zahedan S, Mohagheghi-fard AH (2020) Gene reports prevalence of the bla CTX-M and antibiotic resistance pattern among clinical isolates of Acinetobacter baumannii isolated from Zahedan , Southeast Iran. Gene Reports 19:100626. doi: 10.1016/j.genrep.2020.100626

Alikhani MY, Tabar ZK, Mihani F, Kalantar E (2014) Antimicrobial resistance patterns and prevalence of blaPER-1 and blaVEB-1 genes among ESBLproducing Pseudomonas aeruginosa isolates in West of Iran. Jundishapur Journal of Microbiology 7:1-6. doi: $10.5812 / \mathrm{jjm} .8888$

Alisha Akya etal. (2018) Dissemination of multidrugresistant, class I and II integrons and molecular typing of CTX-M-producing Klebsiella pneumoniae. Int J Appl Basic Med Res 2018 Apr-Jun; 8(2) 100105

Aljindan R, Aljindan R, Bukharie H, et al (2015) Prevalence of digestive tract colonization of Carbapenem resistant Acinetobacter baumannii in hospitals in Saudi Arabia. Journal of Medical Microbiology 64(4):400-406 . doi: 10.1099/jmm.0.000033

Al-mayahie SMG, Jh J, Kuriashy A (2016) Distribution of ESBLs among Escherichia coli isolates from outpatients with recurrent UTIs and their antimicrobial resistance. J Infect Dev Ctries 10, 575-583. doi: 10.3855/jidc.6661

Al-muhanna AS, Al-muhanna S, Alzuhairi MA (2016) Molecular investigation of extended spectrum betalactamase genes and potential drug resistance in clinical isolates of Morganella morganii. Ann Saudi Med. 223-228. doi: 10.5144/0256-4947.2016.223

Alqasim A, Abu A, Almutairi N, et al (2019) Isolation , 
phenotypic and genotypic characterization of Escherichia coli from the bloodstream samples in Riyadh , Saudi Arabia. J King Saud Univ - Sci 4-9. doi: 10.1016/j.jksus.2019.11.043

Alsharapy SA, Gharout-sait A, Muggeo A, et al (2019) Characterization of Carbapenem-resistant Enterobacteriaceae clinical isolates in $\mathrm{Al}$ Thawra University hospital, Sana'a, Yemen. Microbial Drug Resistance 00:00 doi: 10.1089/mdr.2018.0443

Altalhi, A. D., Gherbawy, Y. A., and Hassan SA (2010) Antibiotic resistance in Escherichia coli isolated from retail raw chicken meat in Taif, Saudi Arabia. Foodborne Pathog Dis 7:281-285

Al-tawfiq JA, Stephens G, Memish ZA (2010) Inappropriate antimicrobial use and potential solutions: A Middle Eastern perspective. Expert Rev Anti Infect Ther 8(15):765-774.

Aly SA, Debavalya N, Suh S, et al (2012) Molecular mechanisms of antimicrobial resistance in fecal Escherichia coli of healthy dogs after enrofloxacin or amoxicillin administration. Canadian $\mathrm{J}$ of Microb 58(11):1288-1294. doi: 10.1139/w2012-105

Alyamani EJ, Khiyami AM, Booq RY, et al (2017) The occurrence of ESBL - producing Escherichia coli carrying aminoglycoside resistance genes in urinary tract infections in Saudi Arabia. Ann Clin Microbiol Antimicrob 1-13. doi: 10.1186/s12941-016-0177-6

Ambler RP (1980) The structure of beta-lactamases. Philos Trans R Soc Lond B Biol Sci. 16;289(1036):321-31. doi: 10.1098/rstb.1980.0049.

Aminshahidi M, Arastehfar A, Pouladfar G, et al (2017) Diarrheagenic Escherichia coli and Shigella with high rate of extended-spectrum Beta-Lactamase Production: Microbial drug Resistance 23(8):10371044 doi: $10.1089 / \mathrm{mdr} .2017 .0204$

Amirkamali S, Naserpour-farivar T, Azarhoosh K (2017) Major Article Distribution of the bla OXA , bla VEB-1 , and bla GES-1 genes and resistance patterns of ESBL-producing Pseudomonas aeruginosa isolated from hospitals in Tehran and Qazvin , Iran. Rev Soc Bras Med Trop 50(3):315320. doi: 10.1590/0037-8682-0478-2016

Andersson DI, Hughes D (2010) Antibiotic resistance and its cost: Is it possible to reverse resistance? Nat Rev Microbiol 8:260-271. doi: 10.1038/nrmicro2319

Andersson DI, Levin BR (1999) The biological cost of antibiotic resistance. Curr. Opin. Microbiol. 489493

Antunes NT, Fisher JF (2014) Acquired Class D $\beta$ Lactamases. Antibiotics (Basel) 3:398-434. doi: 10.3390/antibiotics3030398

Arber W (2014) Horizontal Gene Transfer among bacteria and its role in biological evolution. Life (Basel). 4:217-224. doi: 10.3390/life4020217
Armin S, Fallah F, Karimi A, et al (2020) Frequency of extended-spectrum beta-lactamase genes and antibiotic resistance patterns of Gram-negative bacteria in Iran : A multicenter study. Gene Reports 21:100783 doi: 10.1016/j.genrep.2020.100783

Aslantas Ö, Yilmaz ES (2017) Prevalence and molecular characterization of extended-spectrum $\beta$-Lactamase (ESBL) and 5 plasmidic AmpC $\beta$-lactamase (pAmpC) producing Escherichia coli in Dogs. J Vet Med Sci 79, 1024-1030.

Babour IA, Mohamed MB, Shehabi AA (2020) Molecular characterization of Pseudomonas aeruginosa isolates from various clinical specimens in Khartoum / Sudan: Antimicrobial resistance and virulence genes. 10:1-8. doi: 10.3823/840

Badran EF, Din RAQ, Shehabi AA (2016) Low intestinal colonization of Escherichia coli clone ST131 producing CTX-M-15 in Jordanian infants. J. Med. Microbiol 65(2):137-141. doi: 10.1099/jmm.0.000210

Baker-austin C, Wright MS, Stepanauskas R, Mcarthur J V (2006) Co-selection of antibiotic and metal resistance. Trend Microbiol 14(4):176-182:. doi: 10.1016/j.tim.2006.02.006

Baquero F MJ (2000) Mutation frequencies and antibiotic resistance. Antimicrob Agents Chemother 44:17711777.

Baquero F, Negri M (1998) Antibiotic-selective environments. Clin Infect Dis 27: S5-S11.

Baran A, Adiguzel MC (2020) Prevalence of antibioticresistant and extended-spectrum Beta-Lactamaseproducing Escherichia Coli in chicken meat from Eastern Turkey.Pak. Vet. J. 40:355-359 doi: 10.29261/pakvetj/2020.047

Barth M, Peduzzi J, Labia R (1985) Distinction entreles structures primaires des beta-lactamases TEM-1 et TEM-2. Ann. Inst. Pasteur. Microbiol., 136 (3) (1985), pp. 311-321

Bartlett JG, Gilbert DN, Spellberg B (2013) Seven ways to preserve the miracle of antibiotics. Clin Infect Dis 56(10):1445-1450. doi: 10.1093/cid/cit070

Bauernfeind A, Stemplinger I, Jungwirth R, Ernst S (1996) Sequences of B -Lactamase genes encoding CTXM-1 ( MEN-1 ) and CTX-M-2 and relationship of their amino acid sequences with those of other B Lactamases. Antimicrob. Agents Chemother 40:509-513

Baym M, Stone LK, Kishony R (2016) Multidrug evolutionary strategies to reverse antibiotic resistance. Science (New York N.Y.)351:6268. doi: 10.1126/science.aad3292

Bello-López JM, Cabrero-Martínez OA, Ibáñez-Cervantes G, Hernández-Cortez C, Pelcastre-Rodríguez LI, Gonzalez-Avila LU, Castro-Escarpulli G (2019) 
Horizontal gene transfer and its association with antibiotic resistance in the genus Aeromonas spp. Microorganisms 7:363.

Bergman M, Huikko S, Pihlajama M, et al (2004) Effect of macrolide consumption on Erythromycin resistance in Streptococcus pyogenes in Finland in 1997 2001. Clin Infect Dis 38: 1251-1256

Bergman M, Nyberg ST, Huovinen P, et al (2009) Association between antimicrobial consumption and resistance in Escherichia coli. Antimicrob Agents Ch 53: 912-917doi: 10.1128/AAC.00856-08

Bertrand X, Hocquet D (2011) Antibiotic drug resistance: Causes and solutions. EJHP Pract. 17:58-9.

Bialvaei ZA, Samadi H, Asgharzadeh M (2016) CTX-M extended-spectrum -lactamase-producing Klebsiella spp, Salmonella spp, Shigella spp and Escherichia coli isolates in Iranian hospitals. Brazilian $\mathbf{J}$ Microbiol 47:706-711. doi: 10.1016/j.bjm.2016.04.020

Bogaerts P, Bauraing C, Deplano A GY (2007) Emergence and dissemination of BEL-1-Producing Pseudomonas aeruginosa isolates in Belgium. Antimicrob Agents Chemother 51:15841585doi: 10.1128/AAC.01603-06

Bois SK Du, Marriott MS, Ajnyes SGB (1995) Review TEM- and SHV-derived extended-spectrum/ Mactamases: Relationship between selection, structure and function. J. Antimicrob. Chemother.35:7-22

Bokaeian M, Zahedani SS, Bajgiran MS (2015) Frequency of PER , VEB , SHV , TEM and CTX-M genes in resistant strains of Pseudomonas aeruginosa producing extended spectrum $\beta$ Lactamases. Jundishapur J Microbiol. 2015 January; 8(1): e137838. doi: 10.5812/jjm.13783

Bonhoeffer S, Allen RC, Engelsta J, et al (2017) Reversing resistance: different routes and common themes across pathogens. Proc. Biol. Sci. 284

Bonnet R (2004) Growing group of extended-spectrum B Lactamases: the CTX-M enzymes. Antimicrobial agents and 48:1-14. doi: 10.1128/AAC.48.1.1

Bonnet R, Sampaio JLM, Chanal C, et al (2000) A novel class A extended-spectrum B -Lactamase ( BES-1 ) in Serratia marcescens isolated in Brazil. Antimicrob. Agents Chemother. 44:3061-3068

Bonten MJM, Austin DJ, Lipsitch M (2001) Understanding the spread of antibiotic resistant pathogens in hospitals: Mathematical Models as Tools for Control. 1739-1746

Bradford PA, Yang Y, Sahm D, et al (1998) CTX-M-5 , a novel Cefotaxime-Hydrolyzing B -Lactamase from an outbreak of Salmonella typhimurium in Latvia. Antimicrob Agents Chemother 42:1980-1984

Braun SD, Ahmed MFE, El-adawy H, Hotzel H (2016)
Surveillance of extended-spectrum Escherichia coli in dairy cattle farms in the Nile Delta, Egypt. Front Microb 7. doi: 10.3389/fmicb.2016.01020

Burgh S Van, Mansoor IY, Maghdid DM, et al (2018) PME and other ESBL-positive multiresistant Pseudomonas aeruginosa isolated from hospitalized patients in the region of Kurdistan , Iraq.Microb. Drug Resist 25:32-38. doi: 10.1089/mdr.2018.0036

Bush K, Jacoby GA, Medeiros AA (1995) A functional classification scheme for $\beta$-lactamases and its correlation with molecular structure. Antimicrob Agents Chemother 39:1211-1233. doi: 10.1128/AAC.39.6.1211.

Bush, K., Jacoby G. (2012) Beta-lactamase classification and amino acid sequences for TEM, SHV and OXA extended-spectrum and inhibitor resistant enzymes. Available from http//www.lahey.org/Studies (accessed on 27 Octber 2012).

Canto R, Ramo HU (2009) Antibiotic resistance genes from the environment: a perspective through newly identified antibiotic resistance mechanisms in the clinical setting. Clin. Microbiol. Infect. 15 (Suppl. 1):20-25 doi: 10.1111/j.1469-0691.2008.02679.x

CDC (2013) Centers for disease control and prevention, office of infectious disease. Antibiotic resistance threats in the United States. Available online: http://www.cdc.gov/drugresistance/threat-report2013 (accessed on 28 June 2016).

Ceri H, Olson ME, Stremick C, et al (1999) The calgary biofilm device: New technology for rapid determination of antibiotic susceptibilities of bacterial biofilms. J. Clin. Microbiol. 37: 1771-1776

Charrouf FO, Hamze M, Mallat H, et al (2014) Characterization of resistance genes in 68 ESBLproducing Klebsiella pneumonia in Lebanon. Med Mal Infect 44:535-538. doi: 10.1016/j.medmal.2014.10.001

Chen C, Huang M, Chen H, et al (2011) Fusidic acid resistance among clinical isolates of methicillinresistant Staphylococcus aureus in a Taiwanese hospital. BMC Microbiology 2011;11:98.

Christensen BB, Sternberg C, Andersen JBO, et al (1998) Establishment of new genetic traits in a microbial biofilm community. Appl. Environ. Microbiol. 64:2247-2255

Christophy R, Osman M, Mallat H, et al (2017) Prevalence, antibiotic susceptibility and characterization of antibiotic resistant genes among carbapenem-resistant Gram-negative bacilli and yeast in intestinal flora of cancer patients in North Lebanon. J Infect Public Health. 10(6):716-720 doi: 10.1016/j.jiph.2016.10.009

City K, Akya A, Ahmadi M, et al (2019) Prevalence of blaCTX-M, blaCTX-M-2, blaCTX-M-8, blaCTX-M- 
25 and blaCTX-M-3 genes in Escherichia coli isolated from Urinary tract infection in Kermanshah City, Iran. J. Clin. Diagnostic Res. 2019, 13, DC04DC07.

Coculescu B (2009) Antimicrobial resistance induced by genetic changes. J Med Life 2:114-123

Coculescu B.-I. FM (2005) Mecanismul mutaţiilor genice. Rev Med Mil 4 325-333

Comas I, Borrell S, Roetzer A, et al (2012) Whole-genome sequencing of rifampicin-resistant $M$. tuberculosis strains identifies compensatory mutations in RNA polymerase genes. Nat. Genet. 44:106-110. doi: 10.1038/ng.1038.

Cruz F, Garci'a Lobo JM DJ (2002) Antibiotic resistance: how bacterial populations respond to a simple evolutionary force. In: Lewis KA, Salyers AA, Taber HW, Wax RG, eds. Bacterial resistance to antimicrobial. Bacterial resistance to antimicrobial. New York: Marcel Dekker Inc.19-36

Dandachi I, Fayad E, El-bazzal B (2018a) Prevalence of extended-spectrum Beta-Lactamase-producing gram-negative Bacilli and emergence of mor-1 colistin resistance gene in Lebanese swine farms. Micobial Drug Resistance 00:00 doi: 10.1089/mdr.2018.0110

Dandachi I, Fayad E, Sleiman A, et al (2019) Dissemination of multidrug-resistant and mcr-1 gram-negative Bacilli in broilers, farm workers, and the surrounding environment in Lebanon. Micobial Drug Resistance 00:1-10. doi: 10.1089/mdr.2019.0137

Dandachi I, Sokhn ES, Dahdouh EA, et al (2018) Prevalence and characterization of Bacilli isolated from Lebanese poultry: A Nationwide Study. Frontiers in Microbiology 9:1-11. doi: 10.3389/fmicb.2018.00550

Dandachi I, Chaddad A, Hanna J, Matta J, Daoud Z. (2019) Understanding the Epidemiology of Multi-Drug Resistant Gram-Negative Bacilli in the Middle East Using a One Health Approach. Front Microbiol. 10:1941.doi:10.3389/fmicb.2019.01941.

Daoud Z, Salem-sokhn E, Dahdouh E, et al (2017) Resistance and clonality in Escherichia coli and Klebsiella spp., and relationship with antibiotic consumption in major Lebanese hospitals. Integr Med Res. J of global Antimicrobial Resistance 11;45-51 doi: 10.1016/j.jgar.2017.07.011

Dashti AA, Jadaon MM, Amyes SGB (2013) Retrospective Study of an outbreak in a Kuwaiti hospital of multidrug-resistant Klebsiella pneumoniae possessing the new SHV-112 extendedspectrum Beta-Lactamase. $\mathbf{J}$ of Chemotherapy 22(5)335-338 . doi: 10.1179/joc.2010.22.5.335

Dashti AA, Vali L, El-shazly S, Jadaon MM (2014) The characterization and antibiotic resistance profiles of clinical Escherichia coli O25b-B2-ST131 isolates in Kuwait. BMC Microbiol, 14 (2014), p. 214

Datta, N., Kontomichalou P (1965) Penicillinase synthesis controlled by infectious $\mathrm{R}$ factors in Enterobacteriaceae. Nature (London) 208:239-241.

Davies J (1992) Another look at antibiotic resistance. J Gen Microbiol 1992; 1381553-9.

Donlan RM (2001) Biofilm formation: A clinically relevant microbiological process. Emerg Infect Dis7:277-281.

Davies J, Davies D (2010) Origins and evolution of antibiotic resistance. Microbiol Mol Biol Rev 274:417-433. doi: 10.1128/MMBR.00016-10

Davodian, E., Sadeghifard, N., Ghasemian, A., and Noorbakhsh S (2016) Presence of blaPER-1 and blaVEB-1 beta-lactamase genes among isolates of Pseudomonas aeruginosa from south west of Iran. J Epidemiol Glob Heal 6, 211-213

Dehshiri M, Khoramrooz SS, Zoladl M, Khosravani SA (2018) The frequency of Klebsiella pneumonia encoding genes for CTX - M , TEM - 1 and SHV - 1 extended - spectrum beta lactamases enzymes isolated from urinary tract infection. Ann Clin Microbiol Antimicrob 1-7. doi: 10.1186/s12941018-0256-y

Demirbakan, H. et al. (2008) Investigation of plasmidmediated AmpC beta-lactamase types in Klebsiella spp. and Escherichia coli isolates resistant or intermediate to cefoxitin. Mikrobiyol Bul 42, 545551

Demirci-duarte S, Unalan-altintop T, Koseoglu O, Altun B (2020) Fosfomycin resistant isonant. Diagnostic Microbiology and Infect Dis 98(1):115098. doi: 10.1016/j.diagmicrobio.2020.115098

Desin TS (2019) $S$. enteritidis and $S$. typhimurium harboring SPI-1 and SPI-2 are the predominant serotypes associated with human Salmonellosis in Saudi Arabia. Front cell Infect Microb 9:1-12. doi: 10.3389/fcimb.2019.00187

Diab M, Hamze M, Madec J, et al (2016) High prevalence of Non-ST131 CTX-M-15-producing. Microbial Drug Resistance 23(2):261-266. doi: 10.1089/mdr.2016.0019

Ehlers LJ BE (1999) RP4 plasmid transfer among species of Pseudomonas in a biofilm reactor. Wat Sci Tech 1999; 7163-7.

Enne VI, Delsol AA, Roe JM, Bennett PM (2006) Evidence of Antibiotic Resistance Gene Silencing in Escherichia coli. 50:3003-3010. .Antimicrob Agents Chemother doi: 10.1128/AAC.00137-0

Elaldi N, Gozel MG, Kolayli F, et al (2013) Communityacquired CTX-M-15-type ESBL-producing Escherichia coli meningitis: a case report and 
literature review. The journal of Infection In developing Countries 7:05doi: 10.3855/jidc.2820

El-baky RMA, Farhan SM, Ibrahim RA, et al (2020) Antimicrobial resistance pattern and molecular epidemiology of ESBL and MBL producing Acinetobacter baumannii isolated from hospitals in. Alexandria J Med 56:4-13. doi: 10.1080/20905068.2019.1707350

El-ghareeb WR, Abdel-raheem SM, Al-marri T, Alaql F (2020) Isolation and identification of extended spectrum $\beta$-lactamases ( ESBLs ) Escherichia coli from minced camel meat in Eastern province, Saudi Arabia Thai J Vet Med. 2020. 50(2): 155-161.

El-kholy AA, Girgis SA, Shetta MAF, et al (2020) Molecular characterization of multidrug-resistant Gram-negative pathogens in three tertiary hospitals in Cairo, Egypt. European Journal of Clinical Microbiology \& Infectious Diseases 39:987992987-992

Elshamy AA, Aboshanab KM, Yassien MA, Hassouna NA (2020) Prevalence of plasmid-mediated resistance genes among multidrug-resistant uropathogens in Egypt. Afri Health Sci. 20(1):190-8.

El-Shazly et al. (2017) Expanded spectrum $\beta$ - lactamase producing Escherichia coli isolated from chickens with colibacillosis in Egypt. Poult Sci 96, 23752384

Emami A, Bazargani A, Mohammadi AA (2015) Detection of blaPER-1 \& blaOxa10 among imipenem resistant isolates of Pseudomonas aeruginosa isolated from burn patients hospitalized in Shiraz burn hospital. Iranian journal of microbiology, 7(1):7:7-11

Enne VI, Livermore DM, Stephens P, Hall LMC (2001) Persistence of sulphonamide resistance in Escherichia coli in the UK despite national prescribing restriction. Lancet 357(9265):1307-1308

Er H, İş MA, Ik AŞ, R CDEMİ (2015) Seftazidime Dirençli Pseudomonas aeruginosa İ zolatlar 1 nda Beta-Laktamazlar $1 \mathrm{n}$ Moleküler Epidemiyolojisi. Mikrobiyol Bul 49:156-65.

Erdem, I. et al. (2018) Community-acquired lower urinary tract infections: etiology, antimicrobial resistance, and treatment results in female patients. $\mathbf{J}$ Glob Infect Dis 10, 129-132

Evans, B. A. \& Amyes SGB (2014) OXA B-Lactamases. Clinical Microbiology Reviews 27(2):241-263. doi: 10.1128/CMR.00117-13Fisher JF, Meroueh SO, Mobashery S (2005) Bacterial Resistance to -Lactam Antibiotics: Compelling Opportunism , Compelling Opportunity. Chem. Rev. 105:395-424 doi: 10.1021/cr030102i

Evren E, Tekeli A, Oguzman E, Karahan ZC (2019) Characterization of Klebsiella pneumoniae coproducing KPC and NDM-1 Carbapenemases from Turkey Microbial Drug Resistance 1:2 1. doi: 10.1089/mdr.2019.0086

Fam NS, Defasque S, Bert F (2014) Faecal carriage of extended-spectrum $\beta$-lactamase (ESBL ) producing enterobacteria in liver disease patients from two hospitals in Egypt and France: a comparative epidemiological study. Epidemiology and and Infection 143(06):1247-1255 doi: $10.1017 /$ S0950268814001812

Farshadzadeh Z, Dokht A (2014) ScienceDirect Spread of extended-spectrum $b$-lactamase genes of bla OXA10 , bla PER-1 and bla CTX-M in Pseudomonas aeruginosa strains isolated from burn patients. Burns 6-11. doi: 10.1016/j.burns.2014.02.008

Fazeli N, Momtaz H (2014) Virulence Gene Profiles of Multidrug-Resistant Pseudomonas aeruginosa isolated from Iranian hospital infections. Iran Red Crescent Med J. 16(10): e15722. doi: 10.5812 /ircmj. 15722

Feizabadi, M. M. et al. (2010) Distribution of blaTEM, blaSHV, blaCTX-M genes among clinical isolates of Klebsiella pneumoniae at Labbafinejad hospital, Tehran, Iran. Microb Drug Resist. 16:49-53

Fitzpatrick D, Walsh F (2016) Antibiotic resistance genes across a wide variety of metagenomes. FEMS Microbiol Ecol 92:1-8. doi: 10.1093/femsec/fiv 168

Flemming H, Neu TR, Wozniak DJ, et al (2016) The EPS Matrix: The house of biofilm cells. Guest commentary. J of Bacteriology 189:7945-7947. doi: 10.1128/JB.00858-07

Foucault M, Depardieu F, Courvalin P, Grillot-courvalin C (2010) Inducible expression eliminates the fitness cost of vancomycin resistance in enterococci. Proceeding of the National Academy of Sciences 107(39):16964-16969.

Frieden T (2013) Antibiotic resistance threats in the United States. Pp 115. DIANE Publishing Company, USA.

Frieri M, Kumar K, Boutin A (2017) Antibiotic resistance. J Infect Public Health 10:369-378. doi: 10.1016/j.jiph.2016.08.007

Ganjo AR, Maghdid DM, Mansoor IY, Kok DJ, Severin JA, Verbrugh HA, Kreft D, Fatah MH, Alnakshabandi AA, Dlnya A, Hammerum AM, Ng K, Goessens W (2016) 2016. OXA-Carbapenemases present in clinical Acinetobacter baumanniicalcoaceticus complex isolates from patients in Kurdistan, region-Iraq. Microb. Drug Resist 22, 627-637 00: doi: 10.1089/mdr.2015.0060

Gazouli M, Tzelepi E, Markogiannakis A, et al (1998) Two novel plasmid-mediated cefotaxime-hydrolyzing L lactamases (CTX-M-5 and CTX-M-6) from Salmonella typhimurium. FEMS. Microbiol. Lett., 165: 289-293 
Gelder L De, Ponciano M, Abdo Z, et al (2004) Combining mathematical models and statistical methods to understand and predict the dynamics of antibioticsensitive mutants in a population of resistant bacteria during experimental evolution. Genetics 168:11311144. doi: 10.1534/genetics.104.033431

Ghaddar N, Anastasiadis E, Halimeh R, et al (2020) Phenotypic and genotypic characterization of extended-spectrum beta-lactamases produced by Escherichia coli colonizing pregnant women. Infect Dis Obst Gyn 1-7. 10.1155/2020/4190306

Gharout-Sait, A. et al. (2014) Enterobacteriaceae isolates carrying the new delhi metallo-beta-lactamase gene in Yemen. J Med. Microb 63(10)1316-1321. doi: 10.1099/jmm.0.073767-0

Ghassan Tayh et al. (2016) First report of extendedspectrum b -Lactamases among clinical isolates of Klebsiella pneumoniae in Gaza strip, Palestine. Microbial Drug Resistance 23(2):160-176. doi: 10.1089/mdr.2016.0089

Gholipour A, Soleimani N, Shokri D, Mobasherizadeh S (2014) Phenotypic and molecular characterization of extended-spectrum $\beta$-Lactamase produced by Escherichia coli, and Klebsiella pneumoniae isolates in an educational hospital Mohammad Kardi; Azar Baradaran. Jundishapur J Microbiol. 2014 October; 7(10): e11758. doi: 10.5812/jjm.11758

Giakkoupi P, Tzouvelekis LS, Tsakris A, et al (2000) IBC1 , a novel integron-associated class A B -Lactamase with extended-spectrum properties produced by an Enterobacter cloacae Clinical Strain. Antimicrob Agents Chemother 44:2247-2253

Giedraitienė A, Vitkauskienė A, Naginienè R PA (2011) Antibiotic resistance mechanisms of clinically important Bacteria. Medicina, 47:(3)137-146

Girlich D, Poirel L, Schlu A, Nordmann P (2005) TLA-2, a novel ambler class A expanded-spectrum B Lactamase. Antimicrob Agents Chemother 49:47674770. doi: 10.1128/AAC.49.11.4767

Golkar Z, Bagasra O, Pace DG (2014) Bacteriophage therapy: A potential solution for the antibiotic resistance crisis. J Infect Dev Ctries 8(2):129136doi: 10.3855/jidc.3573

Gordon CA, Hodges NA, Marriott C, Polytechnic B (1988) Antibiotic interaction and diffusion through alginate and exopolysaccharide of cystic fibrosis-derived Pseudomonas aeruginosa. J. Antimicrob. Chemother 22:667-674.

Gould IM, Bal AM (2013) New antibiotic agents in the pipeline and how they can help overcome microbial resistance. Virulence 4(2):185-191

Görgeç S, Kuzucu Ç, Otlu B, et al (2015) Genişlemiş Spektrumlu Beta-Laktamaz Üreten Nozokomiyal Escherichia coli İzolatlarında Beta-Laktamaz Gen
Oranları ve Klonal İlişkinin Araştırılması. Mikrobiyol Bul 49:15-25.

Guay DRP (2008) Contemporary management of uncomplicated urinary tract infections. Drugs 68:1169-1205

Guglielmetti E, Korhonen JM, Heikkinen J, Morelli L, von Wright A. (2009) Transfer of plasmid-mediated resistance to tetracycline in pathogenic bacteria from fish and aquaculture environments. FEMS Microbiol Lett. 293(1):28-34.

Hajikarim F, Mehdi M, Dallal S, Reza M (2020) An investigation of extended-spectrum $\beta$-lactamases ( ESBLs ) in Klebsiella isolated from foodborne outbreaks in Iran. Gene Reports 19:100632. doi: 10.1016/j.genrep.2020.100632

Hammad AM, Shimamoto T (2011) Asymptomatic intramammary infection with multidrug-resistant Gram-negative bacteria in a research dairy farm: Incidence and genetic basis of resistance. J. Vet. Med. Sci. 73, 1089-1092

Hassan WM, Hashim A, Domany RAA (2012) Plasmid mediated quinolone resistance determinants qnr, aac $\left(6^{\prime}\right)$-Ib-cr, and qep in ESBL-producing Escherichia coli clinical isolates from Egypt. Indian J Med Microbiol. 30:442-447. doi: 10.4103/02550857.103766

Hassuna NA, Khairalla AS, Farahat EM, Hammad AM (2020) Molecular characterization of producing E . coli recovered from community-acquired urinary tract infections in Upper Egypt. Scientific Report 10:2772 doi: 10.1038/s41598-020-59772-z

Hausner M, Wuertz S (1999) High Rates of Conjugation in Bacterial biofilms as determined by quantitative in situ Analysis. Appl. Environ. Microbiol. 65:3710 3713

Heidary, M., Momtaz, H., and Madani M (2014) Characterization of diarrheagenic antimicrobial resistant Escherichia coli isolated from pediatric patients in Tehran. Iran Iran Red Crescent Med J $16 \mathrm{e} 12329$

Helmy, O. M., and Kashef MT (2017) Different phenotypic and molecular mechanisms associated with multidrug resistance in Gram-negative clinical isolates from Egypt. Infect. Drug Resist. 10:479498.

Hijazi SM, Fawzi MA, Ali FM, et al (1989) Multidrugresistant ESBL-producing Enterobacteriaceae and associated risk factors in community infants in Lebanon. J Infect Dev Ctries 10: 947-955. doi: 10.3855/jidc.7593

Holmes AH, Moore LSP, Steinbakk M, et al (2015) Antimicrobials: access and sustainable effectiveness 2 Understanding the mechanisms and drivers of 
antimicrobial resistance. The lancet 387(10014): 167-187.

Horn DL, Zabriskie JB, Cleary PP, et al (1996) Why Have group A Streptococci remained susceptible to Penicillin? Report on a Symposium. Clin Infect Dis 26:1341-1345.

Hoyle D, Wong KW, William J (1992) Disparate efficacy of tobramycin on $\mathrm{Ca}^{2}-\mathrm{Mg}^{2}$, and HEPES-treated Pseudomonas aeruginosa biofilms. Can J Microbiol 38:1214-8

Hospitals Z, Dabir S, Mohammadi J, et al (2020) Investigation of the Prevalence of CTX-M-1 BetaLactamase gene in Pseudomonas aeruginosa strains isolated from urinary tract infections in Pseudomonas aeruginosa strains isolated from Urina. South Asian Res J Bio Appl Biosci 2(2):2024 doi: 10.36346/sarjbab.2020.v02i02.002

$\mathrm{Hu}$ Y (2017) The antibiotic resistome: Gene flow in environments, animals and human beings. Front Med 11:161-168. doi: 10.1007/s11684-017-0531-x

Huang X, Frye JG, Chahine MA, et al (2012) Characteristics of plasmids in multi-drug-resistant Enterobacteriaceae isolated during prospective surveillance of a newly opened hospital in Iraq. Plose One 7(7) e40360: doi: 10.1371/journal.pone.0040360

Hurdle JG, Neill AJO, Ingham E, et al (2004) Analysis of mpirocin resistance and fitness in Staphylococcus aureus by molecular genetics and structural modeling techniques. Antimicrob. Agents Chemother 48:4366-4376.

Ibuka A, Taguchi A, Ishiguro M, et al (1999) Crystal structure of the E166A mutant of extended- $\hat{E}$ resolution spectrum $\beta$-Lactamase Toho-1 at $1.8 \mathrm{~A}$. resolutions. J. Mol. Biol. 285:2079-2087

Iraz M, Düzgün AÖ, Sandallı C, et al (2015) Distribution of $\beta$-Lactamase genes among carbapenem-resistant Klebsiella pneumoniae strains isolated from patients in Turkey. Ann Lab Med. 35(6):595-601

Izdebski R, Baraniak A, Fiett J, et al (2013) Clonal structure, extended-spectrum beta-lactamases, and acquired AmpC-Type Cephalosporinases of Escherichia coli populations colonizing patients in rehabilitation centers in four countries. Antimicrob Agents Chemother $57: 309-316$ doi: 10.1128/AAC.01656-12

Jamal WY, Albert MJ, Al JET (2015) Emergence of new sequence type OXA-48. Microb Drug Resist, 21: 329-334 doi: 10.1089/mdr.2014.0123

Johnsen J, Silva GJ, Domingues S, et al (2012) Natural transformation facilitates transfer of transposons, integrons and gene cassettes between bacterial species. Plos Pathogens 8(8):e1002837. doi: 10.1371/journal.ppat.1002837
Johnsen PJ, Townsend JP, Bøhn T, et al (2009) Factors affecting the reversal of antimicrobial-drug resistance. doi: 10.1016/S1473-3099(09)70105-7

Wingender J, Strathmann M, Rode A, Leis A, Flemming HC. (2001) Isolation and biochemical characterization of extracellular polymeric substances from Pseudomonas aeruginosa. Methods Enzymol 336:302-14.

Kaiser G.E. (2007) BIOL 230 Microbiology Lecture EText. Community Coll Balt County, Balt Maryland, 2007,student.ccbcmd.edu/courses/bio141/lecguide/u nit2/control/resist .html

Khalaf NG, Eletreby MM, Hanson ND (2009) Characterization of CTX-M ESBLs in Enterobacter cloacae, Escherichia coli and Klebsiella pneumoniae clinical isolates from cairo, Egypt. BMC Infectious Diseases 9:84. doi: 10.1186/1471-2334-9-84

Khan MA, Mohamed AM, Faiz A, Ahmad J Enterobacterial infection in Saudi Arabia: First record of Klebsiella pneumoniae with triple carbapenemase genes resistance. The Journal of Infection in Developing Countries.13(04):334-41. doi: 10.3855/jidc. 11056

Khdair SR, Hassan AM, Wahab HMA, Mahmood NN (2017) Detection of blaCTX-M gene among Pseudomonas aeruginosa isolated from water samples in Baghdad. Al-Mustansiriyah J Sci 28:0-5

Koh E, Kim S (2010) Decline in erythromycin resistance in group A Streptococci from acute pharyngitis due to changes in the emm genotypes rather than restriction of Antibiotic use. The Korean J Lab Med 30(5): 485-490. doi: 10.3343/kjlm.2010.30.5.485

Kolayli F, Gacar G, Karadenizli A, Sanic A (2005) PER-1 is still widespread in Turkish hospitals among Pseudomonas aeruginosa and Acinetobacter spp. FEMS Microbiology Letters249:241-245.doi: 10.1016/j.femsle.2005.06.012

Kon KRM (2016) Antibiotic resistance: can nanoparticles tackle the problem? In: Kon K, Rai M, eds. Antibiotic resistance: Mechanisms and new antimicrobial approaches. Academic Press, Elsevier Inc; USA: 2016. p. 121

Koonin E V, Makarova KS, Aravind L (2001) Horizontal gene transfer in prokaryotes. Annu Rev Microbiol 2001, 55: 709-742

Kristinsson KG (1997) Effect of Antimicrobial Use and Other Risk Factors Antimicrobial Resistance in Pneumococci. Microb Drug Resist 3: 117-123.

Kusradze I, Diene SM, Goderdzishvili M, Rolain J (2011) Molecular detection of OXA carbapenemase genes in multidrug-resistant Acinetobacter baumannii isolates from Iraq and Georgia. International $\mathrm{J}$ of Antimicrobial Agents. International $\mathrm{J}$ of 
Antimicrobial Agents 38:164-168. doi: 10.1016/j.ijantimicag.2011.03.021

Lhwak NS, Abbas YA (2018) Detection of Extended Spectrum $\quad \beta$-Lactmase GeneeCTX-M-1 in Escherchia coli and Klebseilla pneumonia Isolated from Urinary Tract Infection of Pregnant Women in Al-Nassyriah City. J Thi-Qar Sci., 6(4): 92-96

Leangapichart, T. et al. (2016) Downloaded from http://aac.asm.org/ on July 25,2016 by CORNELL UNIVERSITY Downloaded from http://aac.asm.org/ on July 25,2016 by Cornell Universiity collected before and after traveling to Hajj in 2014 to investigate the acquisition of. Antimicrob Agents Chemother 60, 5942-5948. doi: 10.1128/AAC.00669-16

Lerminiaux NA, Cameron AD (2019) Horizontal transfer of antibiotic resistance genes in clinical environments. Can. J. Microbiol 65:34-45

Lesani SS, Soleimani M, Shakib P, Zolfaghari MR (2020) Prevalence of bla CTX-M , bla SHV , and bla TEM genes in Escherichia coli strains isolated from urinary tract infection samples of patients in the intensive care unit in Qom, Iran. 7:2-6. doi: 10.5812/gct.102700.Research

Levin BR, Lipsitch M, Perrot V, et al (1997) The population genetics of antibiotic resistance. Clin Infect Dis 24(Suppl 1):S9-16

Levin BR, Perrot V, Walker N. (2000) Compensatory mutations, antibiotic resistance and the population genetics of adaptive evolution in bacteria. Genetics 154(3):985-97.

Lindgren PK, Marcusson LL, Sandvang D, et al (2005) Biological cost of single and multiple Norfloxacin resistance mutations in Escherichia coli implicated in urinary tract infections. Antimicrob Agents Chemother 49:2343-2351. doi: 10.1128/AAC.49.6.2343

Livermore DM (1995) B -Lactamases in laboratory and clinical resistance. Clinical microbiology Rev8:557584

Livermore DM, Canton R, Gniadkowski M, et al (2007) CTX-M: Changing the face of ESBLs in Europe. J Antimicrob Chemother 59:165-174.

Lopatkin AJ, Meredith HR, Srimani JK, et al (2017) Persistence and reversal of plasmid-mediated antibiotic resistance. Nat Commun 8(1):doi: 10.1038/s41467-017-01532-1

Lorenz MG, Wackernagel W (1994) Bacterial gene transfer by natural genetic transformation in the Environment. Microbial Rev 58:563-602

Lushniak (2014) Antibiotic resistance: a public health crisis. Public Health Rep 129:3-5.
Luyt C, Bréchot N, Trouillet J, Chastre J (2014) Antibiotic stewardship in the intensive care unit. Crit Care. 18(5)480.

Malekjamshidi MR (2020) Prevalence of Extendedspectrum $\beta$-lactamase and integron gene carriage in multidrug-resistant Klebsiella species isolated from outpatients in Yazd, Iran. Iranian J Med Scien 45(1). doi: 10.30476/IJMS.2019.45334.

Maya-Hoyos M, Leguizamón J, Mariño-Ramírez L, Soto CY (2015) Sliding motility, biofilm formation, and Glycopeptidolipid production in Mycobacterium colombiense strains. Biomed Res Int. 2015:2015:419549. doi: 10.1155/2015/419549.

Mcgowan JE (1996) Reasons for the emergence of antibiotic resistance. Am J Med Sci 311:9-16. doi: 10.1016/S0002-9629(15)41625-8

McKeegan KS, Borges-Walmsley MI, Walmsley AR. (2003) The structure and function of drug pumps: an update. Trends Microbiol. 11(1):21-9.

Michael CA, Dominey-howes D, Labbate M, et al (2014) The antimicrobial resistance crisis: causes, consequences, and management. Front Public Health 2:1-8. doi: 10.3389/fpubh.2014.00145

Midilli K (2020) Molecular epidemiology of Carbapenem resistant Enterobacterales Strains Isolated from blood cultures in Antalya, Turkey. Laboratory Science 1-5. doi: 10.1093/labmed/lmaa017

Mihăescu G., Chifiriuc M.C. DLM (2007) Antibiotice şi substanţe chimioterapeutice antimicrobiene. Edn Acad Române, Bucureşti,

Mirsalehian A, Feizabadi M, Nakhjavani FA, Jabalameli F (2010) Detection of VEB-1 , OXA-10 and PER-1 genotypes in extended-spectrum b -lactamaseproducing Pseudomonas aeruginosa strains isolated from burn patients. 36:70-74. doi: 10.1016/j.burns.2009.01.015

Moawad AA, Hotzel H, Neubauer H, et al (2018) Antimicrobial resistance in Enterobacteriaceae from healthy broilers in Egypt: Emergence of colistin resistant and extended - spectrum $\beta$ - lactamase producing Escherichia coli. Gut Pathog 1-12. doi: 10.1186/s13099-018-0266-5

Mobarki NS, Almerabi BA, Hattan AH (2019) Antibiotic resistance crisis. Int J Develop Count 3:561-564

Moubareck CA, Halat DH, Sartawi M, et al (2019) Assessment of performance of CHROMagar KPC and Xpert Carba-R assay for the detection of carbapenem resistant bacteria in rectal swabs: First comparative study from Abu Dhabi, United Arab Emirates. J Global Antimicrob Resist S22137165(19)30187-0. doi: 10.1016/j.jgar.2019.07.021

Munoz Bellido, J. L., M. A. Alonso Manzanares, G. Yague Guirao, M. N. Gutierrez Zufiaurre, M. C. Toldos, M. Segovia Hernandez JA (1999) In Vitro Activities of 
13 Fluoroquinolones against Staphylococcus aureus isolates with characterized mutations in gyrA, gyrB, grlA, andnorA and in vitro activities of 13 fluoroquinolones against Staphylococcus aureus isolates with characterized mutation. Agents Chemother. 43:966- 968.

Musa HA, Osman MAM, Abdelaziz YH, et al (2019) Distribution of extended-spectrum beta-lactamase TEM and CTX-M resistance genes among Proteus species isolated in Sudan. gene reports 21;100909

Musovic S, Oregaard G, Kroer N, Sørensen SJ (2006) Cultivation-Independent Examination of Horizontal Transfer and host range of an IncP-1 plasmid among Gram-Positive and Gram-Negative bacteria indigenous to the Barley rhizosphere. Appl Env Microb72:6687-6692. doi: 10.1128/AEM.00013-06

Naas T, Poirel L, Nordmann P (2008) Minor extendedspectrum b -lactamases. Clin Microbiol Infect14:4252.

Nafiseh Maleki et al (2018) Prevalence of CTX-M and TEM $\beta$-lactamases in Klebsiella pneumoniae isolates from patients with urinary tract infection, Al - Zahra Hospital. Adv Biomed Res 7:10. doi: 10.4103/abr.abr

Nakamura S, Nakamura M, Kojima T, Yoshida H (1989) gyrA and gyrB Mutations in quinolone-resistant strains of Escherichia coli. Agents Chemother. 33:254-255

Namaei MH et al. (2017) First report of prevalence of CTX-M-15-Producing Escherichia coli O25b/ST131 from Iran. Microb Drug Resist 23, 879-884 00:1-6. doi: $10.1089 / \mathrm{mdr} .2016 .0272$.

Nasser M, Ogaili M, Palwe S, Kharat AS (2020) Molecular detection of extended spectrum $\beta$ lactamases, metallo $\beta$-lactamases, and Amp-C $\beta$ lactamase genes expressed by multiple drug resistant Pseudomonas aeruginosa isolates collected from patients with burn/wound infections Burn Open 5:160-166. doi: 10.1016/j.burnso.2020.07.003

Nations D, Soliman AM, Ahmed AM, Shimamoto T (2019) High prevalence of antimicrobial resistance in Gram-Negative bacteria isolated from clinical settings in Egypt: Recalling for judicious use of conventional. Microbial Drug Resistance 00:1-15. doi: $10.1089 / \mathrm{mdr} .2018 .0380$

Nature (2013) The antibiotic alarm. Nature 495:141. doi: $10.1038 / 495141 \mathrm{a}$

Nawfal T, Al-bayssari C, Chabou S, et al (2020) Journal of global antimicrobial resistance intestinal carriage of colistin-resistant Enterobacteriaceae at Saint Georges hospital in Lebanon. Integr Med Res 21:386-390. doi: 10.1016/j.jgar.2019.12.001

Nazik H, Bektöre B, Öngen B, et al (2011) Co-expression of plasmid-mediated quinolone resistance- qnrA1 64 and bla VEB-1 gene in a Providencia stuartii strain. New Microbiol. 34:225-228.

Nazik H, Iplktaç M, Öngen B (2016) Prevalence of qnrA, qnrB, qnrS and aac ( 6 ') -Ib-cr ( in qnr-Positive Isolates ) Among ESBL-positive and / or Ciprofloxacin-iesistant isolates in Turkey. J. Chemother. 21:219-221. 9478:9-12. doi: 10.1179/joc.2009.21.2.219

Nordmannl P, Naas T, Microbiologie S De, et al (1994) Sequence analysis of PER-1 extended-spectrum comparison with class A 13-Lactamases. Antimicrob Agents Chemother 38:104-114

Ochman H, Lawrence JG, Groisman EA (2000) Lateral gene transfer and the nature of bacterial innovation. Nat 405 299-304

Okeke IN, Laxminarayan R, Bhutta ZA, et al (2005) Antimicrobial resistance in developing countries. Part I: Recent trends and current status. Lancet Infect Dis 5:481-493

Olson AB, Silverman M, Boyd DA, et al (2005) Identification of a progenitor of the CTX-M-9 group of Extended-Spectrum $\beta$-Lactamases from Kluyvera georgiana isolated in Guyana. Antimicrob Agents Chemotherapy 49:2112-2115. doi: 10.1128/AAC.49.5.2112

Ombarak, R. A. et al. (2018) Prevalence and molecular characterization of antimicrobial resistance in Escherichia coli isolated from raw milk and raw milk cheese in Egypt. J Food Prot 81, 226-232

Osman KM, Kappell AD, Elhadidy M, et al (2018) Poultry hatcheries as potential reservoirs for antimicrobial-resistant Escherichia coli: A risk to public health and food safety. Sci Rep 1-14. doi: 10.1038/s41598-018-23962-7

Pader V, Hakim S, Painter KL, et al (2016) Staphylococcus aureus inactivates daptomycin by releasing membrane phospholipids. Nature Microbiology 2(1) doi: 10.1038/nmicrobiol.2016.194

Pál T, Sonnevend Á (2019) Epidemic IncX3 plasmids spreading carbapenemase genes in the United Arab Emirates and worldwide. Infect Drug Resist.12:1729-1742

Partridge SR, Kwong SM, Firth N, Jensen SO (2018) Mobile genetic elements associated with antimicrobial resistance. Clin. Microbiol. Rev. 31:161

Paterson DL, Bonomo RA (2005a) Clinical update extended-spectrum Beta-Lactamases: A clinical update. Clin Microbiol Rev 18:657-686. doi: 10.1128/CMR.18.4.657

Paterson DL, Bonomo RA (2005b) Extended-spectrum $\beta$ lactamases: a clinical update. Clin Microbiol Rev18:657-686. doi: 10.1128/CMR.18.4.657 
Paulander W, Maisnier-patin S, Andersson DI (2007) Multiple mechanisms to ameliorate the fitness burden of mupirocin resistance in Salmonella typhimurium. Molecular Biology 64(4):1038-1048. doi: 10.1111/j.1365-2958.2007.05713.x

Peerayeh SN, Rostami E, Siadat SD (2014) High rate of aminoglycoside resistance in CTX-M-15 Producing Klebsiella pneumoniae isolates in Tehran, Iran. Lab Med.45:231-237

Pehlivanoglu F, Turutoglu H, Ozturk D (2016) CTX-M15-Type Extended-Spectrum Beta-Lactamaseproducing Escherichia coli as causative agent of bovine mastitis. Foodborne Pathog. Dis. 13:477482. doi: 10.1089/fpd.2015.2114

Petroni A, Corso A, Melano R, et al (2002) Plasmidic Extended-Spectrum B-Lactamases in Vibrio cholerae O1 El Tor Isolates in Argentina. Antimicrob Agents Chemother 46:1462-1468. doi: 10.1128/AAC.46.5.1462

Peymani A, Farivar TN, Sanikhani R, et al (2014) Emergence of TEM, SHV, and CTX-M-Extended spectrum $\beta$-Lactamases and class 1 Integron among Enterobacter cloacae isolates collected from hospitals of Tehran and Qazvin, Iran. Microb Drug Resist, 20:424-430 10.1089/mdr.2013.0191

Piddock LJ V (2012) The crisis of no new antibiotics- what is the way forward?. The Lancet Infec Dis 12(3);249-253.

Piri F, Ebrahimi MT, Amini K (2018) Short Communication Molecular investigation of CTX - M gene in extended spectrum $\beta$ Lactamases ( ESBLs ) producing Pseudomonas aeruginosa isolated from Iranian patients with burn wound infection. Arch Med Lab Sci. 4(1): 1-4.

Poirel L, Brinas L, Verlinde A, et al (2005) BEL-1, a Novel Clavulanic Acid-Inhibited ExtendedSpectrum $\beta$-Lactamase, and the Class 1 Integron In120 in Pseudomonas aeruginosa. Antimicrob Agents Chemother 49:3743-3748.

Poirel L, Naas T, Nordmann P (2010) Diversity, epidemiology, and genetics of class D B-Lactamases narrow spectrum. Antimicrobial Agents and Chemotherapy 54(1):24-38.

Poirel L, Thomas ILE, Naas T, et al (2000) Biochemical sequence analyses of GES-1, a novel class A extended-spectrum B-Lactamase, and the class 1 integron In52 from Klebsiella pneumoniae. Antimicrob. Agents Chemother 44:622-632.

Poirel L, Weldhagen GF, Naas T, et al (2001) GES-2 , a Class A B-Lactamase from Pseudomonas aeruginosa with increased hydrolysis of imipenem. Antimicrob. Agents Chemother. 44:622-632.

Ponciano M, Joyce P, Top EM, Gelder L De (2007) Stability of a promiscuous plasmid in different hosts:
No guarantee for a long-term relationship. Microbiology 153(2):452-463.

Poole K (2002) Mechanisms of bacterial biocide and antibiotic resistance. J Appl Microbiol 92(1):55-64

Pratt RF, Mcleish MJ (2010) Structural relationship between the active sites of $\beta$-Lactam-Recognizing and amidase signature enzymes: Convergent Evolution? Biochemistry 49(45):9688-9697. doi: 10.1021/bi1012222

Qabajah, M., Awwad, E., and Ashhab Y (2014) Molecular characterisation of Escherichia coli from dead broiler chickens with signs of colibacillosis and ready-to-market chicken meat in the West Bank. Br Poult Sci 55, 442-451 37-41. doi: 10.1080/00071668.2014.935998

Rafiee R, Eftekhar F, Tabatabaei SA, Tehrani DM (2014) Prevalence of extended-spectrum and Metallo $\beta$ Lactamase production in AmpC $\beta$-Lactamase producing Pseudomonas aeruginosa isolates From Burns. Jundishapur J Microbiol, 7:e16436. doi: 10.5812/jjm. 16436

Rahbarnia L, Farajnia S, Khaneshi H, Farajnia H, Naghili B, Tanomand A. Detection of blaOXA-23 and blaNDM-1 carbapenemase among clinical isolates of $A$. baumannii in Tabriz, north-west of Iran. Gene Rep. 2020;18:100555.

Ramadan H, Jackson CR, Frye JG, et al Antimicrobial Resistance, Genetic Diversity and Multilocus Sequence Typing of Escherichia coli from humans , retail chicken and ground beef in Egypt. Pathogens 9, 357

Ramadan, H. H., Jackson CR, Taha SA, Barrett JB, Woodley TA (2018) Contribution of healthy chickens to Antimicrobial-Resistant Escherichia coli associated with human. Vector Borne Zoonotic Dis 18:408-416. doi: 10.1089/vbz.2017.2237

Ranjbar R, Dehkordi FS, Hossein M, et al (2018) Prevalence, identification of virulence factors, Oserogroups and antibiotic resistance properties of Shiga-toxin producing Escherichia coli strains isolated from raw milk and traditional dairy products. Antimicrob Resist Infect Control 7:53.

Review S, Lew W, Pai M, et al (2017) Annals of Internal Medicine Review Initial Drug Resistance and Tuberculosis Treatment Outcomes. Ann Intern Med 2008;149:123-134.

Rezai MS, Salehifar E, Rafiei A, et al (2015) Characterization of multidrug resistant extendedspectrum Beta-Lactamase-producing Escherichia coli among uropathogens of pediatrics in North of Iran. BioMed Res Int. 2015:309478.

Rice EW, Wang P, Smith AL, Stadler LB (2020) Determining hosts of antibiotic resistance genes: A 
review of methodological advances. Env Sci Tech Let 7 (5), 282-291 doi: 10.1021/acs.estlett.0c00202

Rice LB, Sahm D, Binomo RA. (2003) Mechanisms of resistance to antibacterial agents. In: Murray PR, Baron EJ, Jorgensen JH, Phaller MA, Yolken RH, editors. Manual of clinical microbiology. Washington: ASM Press; 2003. p. 1074-101.

Rizi KS, Peerayeh SN, Bakhshi B, Rahbar M (2015) Prevalence of the bla CTX-M-1 group and their transferability in resistant clin- ical isolates of Salmonella serogroups from several hospitals of Tehran. Iran J. Microbiol. 7:203-207

Roberts AP, Pratten J, Wilson M, Mullany P (1999) Transfer of a conjugative transposon, Tn 5397 in a model oral biofilm. FEMS microbial Letters 177:6366.

Roca I, Akova M, Baquero F, et al (2015) The global threat of antimicrobial resistance: science for intervention. New Microbes New Infect 6:22-29. doi: 10.1016/j.nmni.2015.02.007

Ronco E, Naas T, Duport C, et al (1993) Characterization of a Novel Extended-Spectrum 1-Lactamase from Pseudomonas aeruginosa. Antimicrob. Agents Chemother 37:962-969

Rossolini GM, Arena F, Pecile P, Pollini S (2014) Update on the antibiotic resistance crisis. Curr Opin Pharmacol 18:56-60. doi: 10.1016/j.coph.2014.09.006

Runehagen A, Cars H, Sundqvist M, et al (2010) Little evidence for reversibility of trimethoprim resistance after a drastic reduction in trimethoprim use. Journal of Antimicrobial Chrmotherapy. 65(2): 350-360. doi: 10.1093/jac/dkp387

Sabala RF, Usui M, Tamura Y, et al (2020) Prevalence of colistin-resistant Escherichia coli harbouring mcr-1 in raw beef and ready-to-eat beef products in Egypt. Food Control Food Control . 119:107436. doi: 10.1016/j.foodcont.2020.107436

Sabiha SS, Shno JM, Imad MN, Taib A HS (2019) Prevalence and molecular resistance gene in multidrug resistance bacteria, Proteus spp . KJAR KJAR, 3rd International Conference on Health \& Medical Sciences: Insight into Advanced Medical Research (ICHMS 2019).doi: 10.24017/science.2019

Sadeghi A, Halaji M, Shahidi S, et al (2020b) Characterization of extended-spectrum $\beta$ Lactamase-producing uropathogenic Escherichia coli among Iranian kidney transplant patients. BioMed Research International1429-1437.

Salloum T, Panossian B, Bitar I, et al (2020) First report of plasmid-mediated colistin resistance mcr- 8 . 1 gene from a clinical Klebsiella pneumoniae isolate from Lebanon. Antimicrobial Resis \& Infect Cont
9(1):1-7.

Sanschagrin, F.; Couture, F.; Levesque R. (1995) Primary structure of OXA-3 and phylogeny of oxacillinhydrolyzing class D B-Lactamases. Antimicrob Agents Chemother 39:887-893

Sari AN, Bİçmen M, Gülay Z (2013) Investigation of plasmid mediated AmpC Beta-Lactamases among Escherichia coli and Klebsiella pneumoniae isolated from blood cultures. J Pak Med Assoc47:582-591

Schill F, Abdulmawjood A, Klein G, Reich F (2017) Prevalence and characterization of extendedspectrum $\beta$-lactamase (ESBL) and AmpC $\beta$ lactamase producing Enterobacteriaceae in fresh pork meat at processing level in Germany. Int $\mathbf{J}$ Food Microbiol 257:58-66. doi: 10.1016/j.ijfoodmicro.2017.06.010

Senka D, Šušković J, Blaženka K (2008) Antibiotic resistance mechanisms in Bacteria: Biochemical and genetic aspects. Food Technol Biotechnol 46:11-21

Seppala H, Klaukka T, Vuopio-Varkila J, Muotiala A, Helenius H, Lager K, Huovinen P (1997) The effect of changes in the consumption of macrolide antibiotics on erythromycin resistance in group A Streptococci in Finland. The New England Journal of Medicine 337(7):441-446

Shadi Beladi Ghannadi, Maryam Ghane LB (2019) Determination of antibiotic resistance pattern and frequency of CTX-M , TEM , and SHV B Lactamase encoding genes among Shigella isolates from inpatients in Tehran, Iran. Mljgoums, 13(2) 815.

Shaikh S, Fatima J, Shakil S, et al (2014) Antibiotic resistance and extended spectrum beta-lactamases: Types, epidemiology and treatment. King Saud University. Saudi J Biol Sci. 22(1):90-101

Shaker NB, Omar K, Ali M (2020) Molecular detection of some antibiotic resistant genes of bacteria isolated from bloodstream infections of hemodialysis patients. Medico Legal Update 20(1);1373-1378.

Shakib, P. et al. (2018) Detection of extended-spectrum beta-lactamases (ESBLs) and antibiotic susceptibility patterns in Klebsiella pneumoniae in western, Iran. Infect Disord Drug Targets 18, 156163

Sharma D, Misba L, Khan AU (2019) Antibiotics versus biofilm: an emerging battleground in microbial communities. Antimicrob. Resist. Infect. Control 8, 76-76.

Shayan S, Bokaeian M (2015) Detection of ESBL - and AmpC - producing $E$. coli isolates from urinary tract infections. Adv. Biomed. Res. 4:220 doi: 10.4103/2277-9175.166643

Sheikh YA Al, Marie MAM, John J, et al (2014) Prevalence of $16 \mathrm{~S}$ rRNA methylase genes among 
beta-lactamaseproducing enterobacteriaceae clinical isolates in Saudi Arabia. Libyan J Med. 9:24432. doi: 10.3402/ljm.v9.24432

Shibl AM, Al-agamy MH, Khubnani H, et al (2012) High prevalence of acquired quinolone-resistance genes among Enterobacteriaceae from Saudi Arabia with CTX-M-15 $\beta$-lactamase. Diagn Microbiol Infect Dis. 73:350-353. 10.1016/j.diagmicrobio.2012.04.005

Silva J, Aguilar C, Ayala G, et al (2000) TLA-1 : a New Plasmid-Mediated Extended-Spectrum B-Lactamase from |Escherichia coli. Agents Chemother. 44:9971003

Sirot D, Sirof J, Morand RLA, Courvalin P (1987) Transferable resistance to third-generation cephalosporins in clinical isolates of Klebsiella pneumoniae: Identification of CTX-1, a novel / Mactamase. J. Antimicrob. Chemother. 20:323-334

Sitaraman R (2018) Prokaryotic horizontal gene transfer within the human holobiont: Ecologicalevolutionary inferences, implications and possibilities. Microbiome 6(1):163

Sivertsen A, Pedersen T, Larssen W, et al (2016) A silenced vanA gene cluster on a transferable Plasmid caused an outbreak of Vancomycin-variable Enterococci. Antimicrobial Agents and Chemotherapy 60(7):4119-4127. doi: 10.1128/AAC.00286-16.Address

Sjölund M, Wreiber K, Andersson DI, Blaser MJ EL (2003) Brief communication long-term persistence of resistant Enterococcus species after antibiotics to eradicate Helicobacter pylori. Annals of internal medicine. 139:483-487

Skurnik D, Clermont O, Guillard T, et al (2015) Emergence of antimicrobial-resistant Escherichia coli of animal origin spreading in humans. Molecular Biology and Evolution 33(4):898-914. doi: 10.1093/molbev/msv280

Sougakoff W, Goussard S, Courvalin P (1988) The TEM-3 fl-lactamase, which hydrolyzes broad-spectrum cephalosporins, is derived from the TEM-2 penicillinase by two amino acid substitutions. FEMS Microbiology Letters 56:343-348

Subbiah M, et al (2011) Selection pressure required for long-term persistence of blaCMY-2-Positive IncA/C plasmids. Appl Env Microb 77:4486-4493. doi: 10.1128/AEM.02788-10

Sundqvist M (2014) Reversibility of antibiotic resistance Reversibility of antibiotic resistance. Upsala $\mathrm{J}$ of Medical Sciences 119(2):142-148. doi: 10.3109/03009734.2014.903323

Tian G, Wang H, Zhang A, et al (2012) Detection of clinically important $\beta$-lactamases in commensal Escherichia coli of human and swine origin in western China Printed in Great Britain. J Med Micobiol 61:233-238.

Tawfik AF, Shibl AM, Aljohi MA, et al (2012) Distribution of Ambler class A, B and D b lactamases among Pseudomonas aeruginosa isolates. Burns 38:855-860. doi: 10.1016/j.burns.2012.01.005

Tayh G, Nagarjuna D, Sallem R Ben, et al (2020) Original article First report of VIM metallo- $\beta$-lactamase production in Escherichia coli and Klebsiella pneumoniae clinical isolates from Gaza Strip , Palestine. Germs 10(1):18-26

Todar K (2008) Bacterial resistance to antibiotics. Todar's online textbook of bacteriology Univ Wisconsin, 2008. http//www.textbookofbacteriol ogy.net/

Tzouvelekis LS, Tzelepi E, Tassios PT, Legakis NJ (2000) CTX-M-type $\beta$-lactamases: An emerging group of extended-spectrum enzymes. Int. J. Antimicrob. Agents14:137-142

van Hoek AH, Mevius D, Guerra B, Mullany P, Roberts AP, Aarts HJ. (2011) Acquired antibiotic resistance genes: an overview. Front Microbiol. 28;2:203. doi: 10.3389/fmicb.2011.00203.

Varela MF, Kumar S (2014) Molecular mechanisms of bacterial resistance to antimicrobial agents. In: Microbial pathogens and strategies for combating them: science, technology and education. MéndezVilas, A., Ed.; Formatex Research Center: Badajoz, Spain. 522-534

Verraes C, Boxstael S Van, Meervenne E Van, Coillie E Van (2013) Antimicrobial resistance in the food chain: A Review. Int $J$ Env Res Pub Health 10(7):2643-2669. doi: 10.3390/ijerph10072643

Vilhelmsson SE, Tomasz A (2000) Molecular evolution in a Multidrug-Resistant Lineage of Streptococcus pneumoniae: Emergence of strains belonging to the serotype 6B Icelandic clone that lost antibiotic resistance traits. J Clin Microb 38(4):1375-1381.

Viswanathan VK (2014) Off-label abuse of antibiotics by bacteria. Gut Microbes 5:1, 3-4.

Walther-rasmussen J, Høiby N (2006) OXA-type carbapenemases. Antimicrobial Chemotherapy 57(3):373-383. doi: 10.1093/jac/dki482

Wang W, Arshad MI, Khurshid M, et al (2018) Antibiotic resistance: A rundown of a global crisis. Infection and Drug Resistance 1645-1658

Weldhagen GF, Poirel L, Nordmann P (2003) Ambler class A extended-spectrum $\beta$-Lactamases in Pseudomonas aeruginosa: Novel developments and clinical impact. Antimicrobial Agents and Chemotherapy 47:2385-2392.

Williams I, Venables WA, Lloyd D, et al (1997) The effects of adherence to silicone surfaces on antibiotic susceptibility in Staphylococcus aureus. Microbiology 143:2407-13 
Whitchurch CB, Tolker-nielsen T, Ragas PC, Mattick JS (2002) Extracellular DNA required for Bbcterial biofilm formation. Science 295(5559):1487

Wilson DN (2014) Ribosome-targeting antibiotics and mechanisms of bacterial resistance. Nat Publ Gr 12:35-48. doi: 10.1038/nrmicro3155

Wintersdorff CJH Von, Penders J, Niekerk JM Van (2016) Dissemination of antimicrobial resistance in microbial ecosystems through horizontal gene transfer. Front Microb 7:1-10. doi: 10.3389/fmicb.2016.00173

Wise R (2002) Antimicrobial resistance: priorities for action. J Antimicrob Chemother 49:585-586

Woodford N, Livermore DM (2009) Infections caused by Gram-positive bacteria: A review of the global challenge. J Infect 59:S4-S16. doi: 10.1016/S01634453(09)60003-7

Wright GD (2005) Bacterial resistance to antibiotics: Enzymatic degradation and modification. Advanced Drug Delivery Reviews 57(10);1451 - 1470. doi: 10.1016/j.addr.2005.04.002.

Wright GD (2014) something old, something new: revisiting natural products in antibiotic drug discovery. Can J Microbiol. 2014;60(3):147-154.

Yalew ST (2020) Review on Antibiotic Resistance: Resistance mechanisms, methods of detection and its controlling strategies. Biomedical Research Network+, LLC 24(5):18651-18657 doi: 10.26717/BJSTR.2020.24.004121

Yasir M, Ajlan AM, Shakil S, Jiman-fatani AA (2018) Molecular characterization, antimicrobial resistance and clinico- bioinformatics approaches to address the problem of extended- spectrum $\beta$-lactamaseproducing Escherichia coli in western Saudi Arabia. Sci. Rep. 8:14847. doi: 10.1038/s41598-018-330938

Yigit H, Queenan AM, Anderson GJ, et al (2001) Novel carbapenem-hydrolyzing $\beta$-Lactamase , KPC-1 , from a carbapenem-resistant strain of Klebsiella pneumoniae. Antimicrob. Agents Chemother 45:1151-1161. doi: 10.1128/AAC.45.4.1151

Yilmaz NO, Agus N, Bozcal E, et al (2013) Detection of plasmid-mediated AmpC B -lactamase in Escherichia coli and Klebsiella pneumoniae. Indian Journal of Medical Microbiology. 31(1): 53-59. 